Portland State University

PDXScholar

Summer 9-7-2017

\title{
Detecting Change in Rainstorm Properties from 1977-2016 and Associated Future Flood Risks in Portland, Oregon
}

\author{
Alexis Kirsten Cooley \\ Portland State University
}

Follow this and additional works at: https://pdxscholar.library.pdx.edu/open_access_etds

Part of the Geography Commons, and the Hydrology Commons

Let us know how access to this document benefits you.

\section{Recommended Citation}

Cooley, Alexis Kirsten, "Detecting Change in Rainstorm Properties from 1977-2016 and Associated Future Flood Risks in Portland, Oregon" (2017). Dissertations and Theses. Paper 3889.

https://doi.org/10.15760/etd. 5777

This Thesis is brought to you for free and open access. It has been accepted for inclusion in Dissertations and Theses by an authorized administrator of PDXScholar. Please contact us if we can make this document more accessible: pdxscholar@pdx.edu. 
Detecting Change in Rainstorm Properties from 1977-2016 and Associated Future

Flood Risks in Portland, Oregon

by

Alexis Kirsten Cooley

A thesis submitted in partial fulfillment of the

requirements for the degree of

\author{
Master of Science \\ in \\ Geography
}

Thesis Committee:

Heejun Chang, Chair

Andrés Holz

Paul C. Loikith

Portland State University

2017 
(C) 2017 Alexis Kirsten Cooley 


\begin{abstract}
In response to increased greenhouse gases and global temperatures, changes to the hydrologic cycle are projected to occur and new precipitation characteristics are expected to emerge. The study of these characteristics is facilitated by common indices to measure precipitation and temperature developed by the Expert Team on Climate Change Detection and Indices (ETCCDI). These indices can be used to describe the likely consequences of climate change such as increased daily precipitation intensity (SDII) and heavier rainfall events (R95p). This study calculates a subset of these indices from observed and modelled precipitation data in Portland, Oregon. Five rainfall gages from a high resolution rain gage network and projections from three downscaled global climate models including CanESM2, CESM1, CNRM-CM5 are used to calculate precipitation indices. Mann-Kendall's tau is used to detect monotonic trends in indices. The observational record is compared with models for the historic period (1977-2005) and these past trends are compared with projected future trends (2006-2100). The influence of study unit on trend detection is analyzed by computing trends at the annual and monthly scale. Study unit is show to be important for trend detection. When the annual study unit is used, projected future trends towards increased precipitation intensity and event volumes are not observed in the historic data. However, when analyzed with a monthly study unit, trends towards increased precipitation intensity and event volumes are observed in the historic data. These trends are shown to be important for Portland area flooding, as precipitation indices are shown to significantly correlate with 40 maximum peak flow events that occurred during the period of study.
\end{abstract}




\section{Acknowledgements}

I would like to acknowledge the Willamette National Forest as the source of my inspiration to study hydrology. The need to protect forests and the amazing creatures within gave me the courage to pause my career and return to graduate school.

Thanks to my dear friends, family, and feline critters who helped me let go of my life in Washington, DC and make a new start in Portland, OR.

Thanks to mentors who encouraged my pursuit of science and helped me navigate the graduate admission process including Yu Zhang, Marion Dresner, Emad Habib and Greg Carbone.

I would like to express gratitude to my advisor Heejun Chang for countless hours of discussion and guidance throughout my graduate program. Selecting the right adviser is a critical part of success in graduate school, and I have not been disappointed. I am also grateful to my thesis committee members Paul Loikith and Andrés Holz for their ideas and support which was vital to my research.

Thanks to the Urban Resilience to Extremes (UREx), Sustainability Research Network (SRN) fellowship which with assistance from the National Science Foundation has supported my graduate work. It has been an honor to participate in a rich network of researchers and practitioners.

Thanks and acknowledgement to the World Climate Research Programme's Working Group on Coupled Modelling, which is responsible for the Coupled Model 
Intercomparison Project (CMIP5) and the CMIP5 climate modeling groups (listed in Table 3 of this paper) for making available their model output.

I appreciate very much SRN colleague Andrew Ballinger for assistance in obtaining downscaled CMIP5 Climate and Hydrology projections. The Localized Constructed Analogues (LOCA) downscaling approach he introduced me to benefited this research by providing data relevant for Portland, OR. This expanded the value of my thesis research, and I am grateful for his help. 


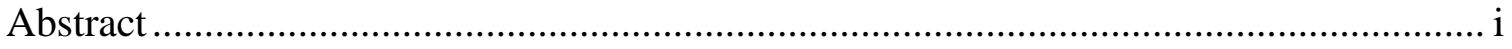

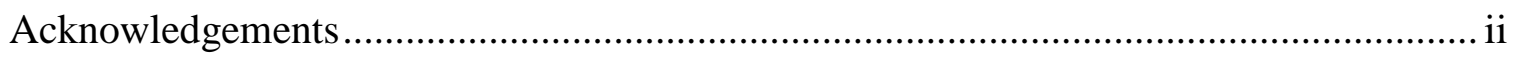

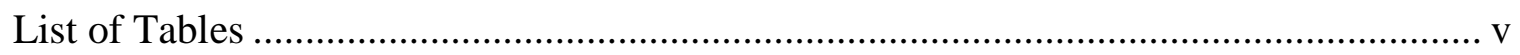

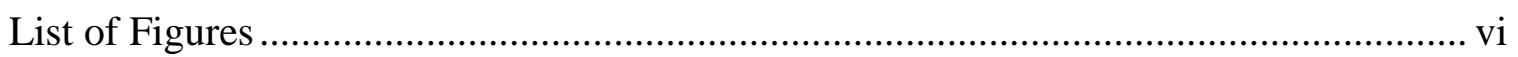

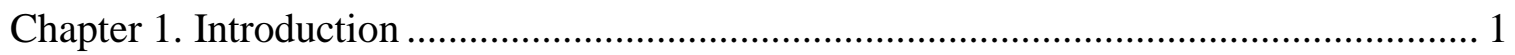

1.1 Precipitation and climate change ...................................................... 1

1.2 Research Questions ............................................................................ 4

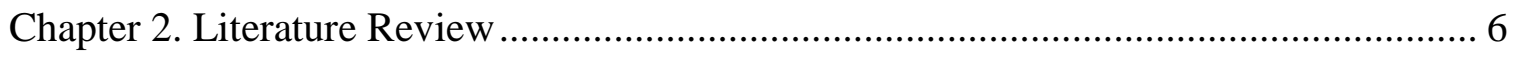

2.1 Synthesizing Global Precipitation Trends ........................................... 6

2.2 Pacific Northwest Climate .............................................................. 11

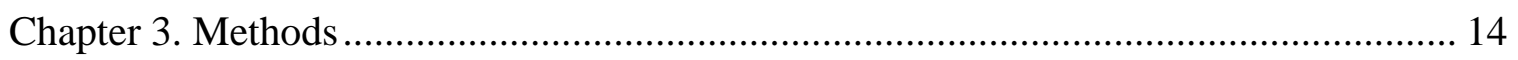

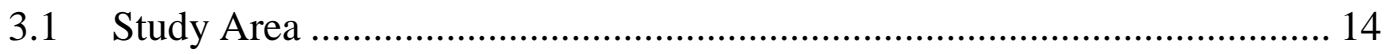

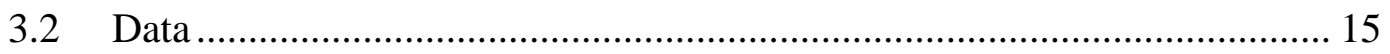

3.3 Methods for Question 1: Comparisons with downscaled climate models.. 18

3.4 Methods for Question 2: Comparing annual and monthly trends .............. 21

3.5 Methods for Question 3: ETCCDI Indices and Peak Streamflow .............. 24

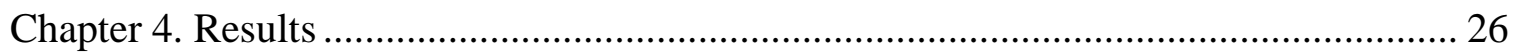

4.1 Results for Question 1: Comparisons with downscaled global climate models ............................................................................................... 26

4.2 Results for Question 2: Comparing annual and monthly trends ................ 29

4.3 Results for Question 3: ETCCDI Indices and Peak Streamflow ............... 33

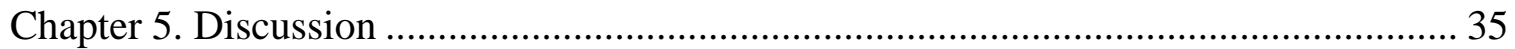

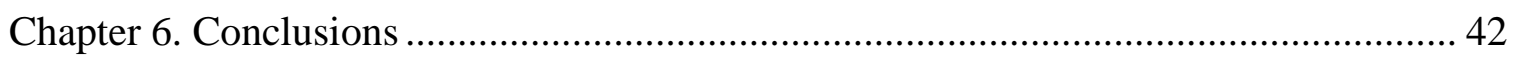

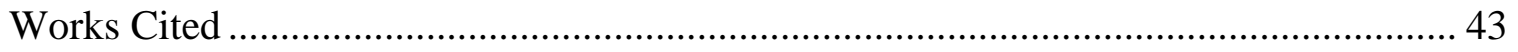

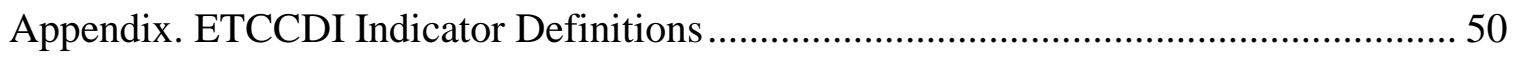




\section{List of Tables}

Table 1. Review of global literature using ETCCDI indices........................................ 7

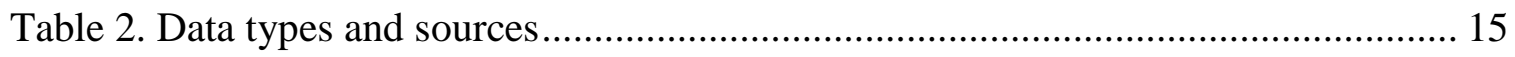

Table 3. Global climate models used and creator .......................................................... 17

Table 4. Recording time of atmospheric soundings..................................................... 18

Table 5. Definition of ETCCDI indices used for Research Question 1 ........................... 19

Table 6. Definition of ETCCDI indices used for Research Question 2 .......................... 22

Table 7. Comparison of annual index trends for 1977-2005 and 2006-2100 .................. 29 


\section{List of Figures}

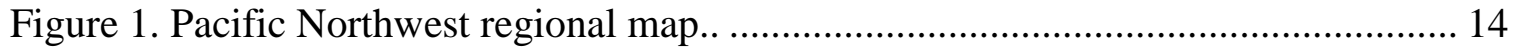

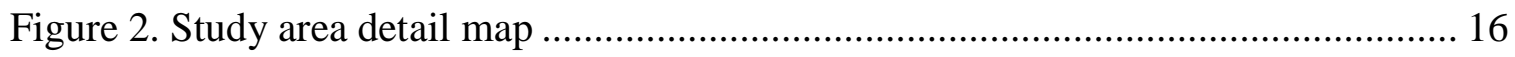

Figure 3. Expected change to ETCCDI indices for 2006-2100 (Giorgi et al. 2014)....... 20

Figure 4. Index trends from observations and climate models for 1977-2005 including

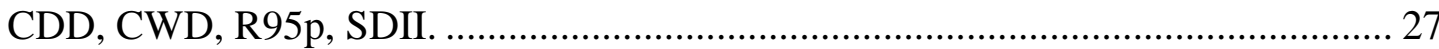

Figure 5. Annual index trends from climate models for 2006-2100 including CDD,

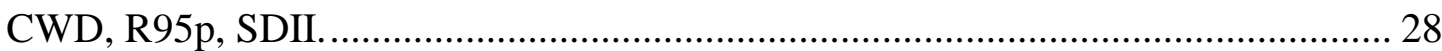

Figure 6. Annual index trends for Portland, OR observations for 1977-2016 including PRCPTOT, Rx1day, Rx5day, SDII, TNn, TXx................................................. 30

Figure 7. Monthly index trends for Portland, OR observations for 1977-2016 including Rx1day, Rx5day, PRCPTOT..

Figure 8. Monthly index trends for Portland, OR observations for 1977-2016 including TNn, TXX.

Figure 9. Monthly index trends for Portland, OR observations for 1977-2016 including daily scale rain intensity (SDII)..

Figure 10. Monthly index trends for Portland, OR observations for 1977-2016 including hourly scale rain intensity (SDII-Hourly).

Figure 11. Monthly index trends for atmospheric soundings at 700mb for 1977-2016 including TXx, TNn.

Figure 12. Kendall rank coefficients for correlation of monthly indices and peak flow at Johnson Creek during 40 maximum flow events occurring from 1977-2016. 


\section{Chapter 1. Introduction}

\subsection{Precipitation and climate change}

As a consequence of rising levels of greenhouse gases, changes to the global hydrologic cycle are anticipated to occur. Change to patterns of precipitation are confidently expected in part because a warmer atmosphere can hold additional water vapor, as described by the Clausius-Clapeyron model of gas behavior under conditions of temperature increase (Huntington, 2006). The effects of temperature rise on precipitation will vary but include the possibilities for altered routes of water vapor transport in atmospheric circulation, and different seasonal precipitation patterns (Held and Soden, 2006; Wentz et al., 2007; Trenberth, 2011). Although the physical basis for precipitation change is well-established, the delivery of a consistent, statistically confident message about global precipitation trends is hampered by spatial and temporal variability of trends (IPCC, 2013).

As mentioned above, global shifts in precipitation regime are expected to already be occurring because global temperature rise is certain (IPCC, 2013). An increase in atmospheric water vapor has been observed globally, and some models suggest changes in tropical and sub-tropical rainfall cannot be explained without a global greenhouse gas signal (Hense et al., 1988; Zhang et al., 2007). Many other precipitation trends have been detected around the world, but with varying periods of study and measurement techniques, these studies could be anecdotal or site-specific rather than connected by the 
underlying warming trend (Groisman et al. 1999; Osborn et al., 2000; Groisman et al., 2005; Krishnamurthy et al., 2009; Soulis et al., 2016).

It is important to consider regional changes in precipitation in order to identify emerging change to the hydrologic cycle. Although mean precipitation increased in midlatitude land areas since 1951, trends at other latitudes are less confident (IPCC, 2013). From 1950-2008 regions in the Middle East and Northern Africa experienced increased aridity (Dai, 2011). This is evidence of the need for regional studies and the inadequacy of using a single metric for the entire globe. Recalling Köppen-Geiger's climate classification of 30 distinct temperature and precipitation regimes, an understanding of different changes in different places is necessary (Peel et al., 2007). Analysis of change in areas of different latitudes provides some insight into how different climates may experience new precipitation signals (IPCC, 2013). Studies that go further to consider how the five Köppen climate types (arid, tropical, temperate, continental, cold) may shrink and expand also enhances regional projections (Rubel and Kottek, 2010). Recalling that new precipitation regimes may have severe consequences for society and environment through pathways of increased flood or drought, the importance of understanding regional response to changing precipitation regimes is high (McMichael et al., 2006).

Regional studies conducted with methodology that is standardized and replicable can contribute to the synthesis of global results. In recognition that many studies of precipitation existed but did not lend themselves to comparison because of unique methodologies, the development of common metrics for measuring change to 
precipitation was needed (Moberg et al., 2006). Recognition of this fact led to the creation of a number of common indices by different scientific communities such as those created on behalf of the World Meteorological Organization (WMO) by the Expert Team on Climate Change Detection and Indices (ETCCDI) group as well as those created by the European and North Atlantic daily to multi-decadal climate variability (EMULATE) groups (Zhang et al., 2011). The formulas for creating these indices are published online and tools to automate their calculation such as RClimDex are available.

This study will use standardized ETCCDI indices to investigate precipitation trends in Portland, OR for the past and future. An observational record from 1977 - 2016 is used, along with past and future projections from global climate models CanESM2, CESM1-CAM5, and CNRM-CM5 that were statistically downscaled by Pierce et al. to represent the Portland, OR climate (2014). In addition, the role of temporal scale and period of study in the ETCCDI methodology are explored. This study aims to address how selection of temporal parameters can enhance our understanding of regional climate trends.

This study also explores the adequacy of ETCCDI to reflect surface hydrology. Precipitation regime change poses increased risks of natural hazards. This study will evaluate how well ETCCDI precipitation indices characteristics can reflect maximum streamflow discharge events. ETCCDI indices are built for the use of daily data, and the use of such low resolution data may be inadequate to reflect discharge (Hershfield, 1963). Other studies have examined how precipitation indices can correlate to discharge, and 
this study will expand this work by using standard ETCCDI indices rather than custom measurements (Pielke and Downton, 2000).

\subsection{Research Questions}

The first purpose of this work is to use standard indices of precipitation to facilitate comparison between Portland's past and future climate. Key precipitation indices are calculated for the Portland climate, and compared with historic (1977-2005) and future (2006-2100) projections from three regionally downscaled global climate models. The specific ETCCDI indicators that Giorgi et al. (2014) hypothesized would change in response to climate change will be compared for the different datasets. This technique will provide insight into whether the expected climate change signals are observed in Portland.

A second question investigates the role of temporal unit of study and data resolution in precipitation and temperature trend detection. Select ETCCDI indices are calculated for the Portland 1977-2016 observational record at the monthly and annual scale to determine whether a finer unit of analysis can improve trend detection. Further, although ETCCDI methodology uses daily data, select indices are also calculated at the hourly scale to determine whether higher resolution data can improve trend detection.

Finally, the role of ETCCDI indices for applied hydrologic applications is explored by examining how well precipitation indices compare with peak streamflow discharge events in a flood-prone creek. 
This research will address the following research questions:

1. Do ETCCDI climate measurements for precipitation in Portland, OR, fit future or historic climate model projections?

2. How does changing the study unit from annual to monthly and the data resolution from daily to hourly influence trend detection?

3. How well do ETDCCI indices correlate with maximum flow events at Johnson Creek? 


\section{Chapter 2. Literature Review}

\subsection{Synthesizing Global Precipitation Trends}

The ETCCDI indices provide standard methods for evaluating change to climate extremes around the world (Zhang et al., 2011). A number of workshops to train scientists in the use of ETCCDI indices and calculate them for different national datasets took place between 1998 and 2004. The Asia-Pacific Network for Global Change Research (APN) sponsored a number of workshops in the eastern hemisphere, while the US State Department sponsored several in both eastern and western hemispheres (Peterson and Manton, 2008). Analysis of national datasets that occurred during these workshops was used in the preparation of the Third and Fourth Annual IPCC Reports. Reviewing studies that use the ETCCDI discovered their widespread use in Asia and Africa, perhaps a result of the APN sponsorship (Table 1).

The study of extremes is facilitated by the ETCCDI indices that employ techniques to examine events occurring at the minimum and maximum of temperature and precipitation ranges. Many of the ETCCDI indices were designed specifically to study extremes. The indices accomplish this by calculating the frequency that certain thresholds are exceeded (Peterson and Manton, 2008). For example, the TN90p and TN10p indices measure how often minimum temperatures exceed or are less than the $90^{\text {th }}$ and $10^{\text {th }}$ percentile of temperatures from a thirty-year baseline period. Similar indices exist for maximum temperature and precipitation. 
Reviews of regional studies employing ETCCDI indices demonstrate consistent temperature increase and disparate precipitation trends. Globally consistent trends in annual minimum temperature (TNn) is notable. However, the lack of a consistent monotonic precipitation trend, also identified in the IPCC report, is also apparent (IPCC, 2013). Although trends were found in ETCCDI precipitation indices like rainfall intensity (SDII) and precipitation total (PRCPTOT), trends are not consistently positive or negative. There is a distinct lack of clarity on the mechanisms creating spatially incoherent trends. Increases to intensity and maximum single day rainfall (SDII, Rx 1day) are present in many studies, but these trends are rarely consistent across the entire study area (Rahimzadeh et al., 2009; Dumitresu et al., 2015).

\begin{tabular}{|c|c|c|c|c|c|c|}
\hline $\begin{array}{l}\text { Cont- } \\
\text { inent }\end{array}$ & Region & $\begin{array}{l}\text { Köp- } \\
\text { pen } \\
\text { Clim- } \\
\text { ate }\end{array}$ & Years & Scale & Author & Summary \\
\hline Asia & India & $\begin{array}{l}\text { Variet } \\
\text { y of } \\
\text { A, B, } \\
\text { C, D } \\
\text { climat } \\
\text { es }\end{array}$ & $\begin{array}{l}1901- \\
2004\end{array}$ & Annual & $\begin{array}{l}\text { Panda et al., } \\
2016\end{array}$ & $\begin{array}{l}\text { Increase: SDII, R95p, } \\
\text { R99pTOT. } \\
\text { Decrease: CWD (monsoon } \\
\text { region). No temperature } \\
\text { indices used. }\end{array}$ \\
\hline Asia & Indonesia & $\begin{array}{l}\text { Af, } \\
\text { Am, } \\
\text { Aw }\end{array}$ & $\begin{array}{l}1983- \\
2012\end{array}$ & $\begin{array}{l}\text { Season- } \\
\text { al }\end{array}$ & $\begin{array}{l}\text { Tangang et } \\
\text { al., } 2017\end{array}$ & $\begin{array}{l}\text { Increase: TX90p, TN90p, } \\
\text { SDII (winter/spring), Rx1day } \\
\text { (winter/spring). } \\
\text { Decrease summer: SDII } \\
\text { (summer, southern regions), } \\
\text { Rx1day (summer, southern } \\
\text { regions). }\end{array}$ \\
\hline Asia & Iran & $\begin{array}{l}\text { Csa, } \\
\text { Bsk, } \\
\text { Bwk, } \\
\text { Dsa, } \\
\text { Dsb }\end{array}$ & $\begin{array}{l}1951- \\
2003\end{array}$ & Annual & $\begin{array}{l}\text { Rahimzadeh } \\
\text { et al., } 2009\end{array}$ & $\begin{array}{l}\text { Increase: TX90p, TN90p, } \\
\text { SDII (north region). } \\
\text { Decrease: PRCPTOT (two- } \\
\text { thirds of country) }\end{array}$ \\
\hline
\end{tabular}




\begin{tabular}{|c|c|c|c|c|c|c|}
\hline $\begin{array}{l}\text { Cont- } \\
\text { inent }\end{array}$ & Region & $\begin{array}{l}\text { Köp- } \\
\text { pen } \\
\text { Clim- } \\
\text { ate }\end{array}$ & Years & Scale & Author & Summary \\
\hline $\begin{array}{l}\text { Eur- } \\
\text { ope }\end{array}$ & Romania & $\begin{array}{l}\text { Dfc } \\
\text { Dfb } \\
\text { Dfa } \\
\text { Cfa } \\
\text { Et }\end{array}$ & $\begin{array}{l}1961- \\
2013\end{array}$ & $\begin{array}{l}\text { Season- } \\
\text { al }\end{array}$ & $\begin{array}{l}\text { Dumitrescu } \\
\text { et al., } 2015\end{array}$ & $\begin{array}{l}\text { Increase: SU, WSDI, R10mm } \\
\text { (various sub-regions), R20mm } \\
\text { (various sub-regions), SDII } \\
\text { (various sub-regions). } \\
\text { Decrease: FD, SDII (various } \\
\text { sub-regions). }\end{array}$ \\
\hline $\begin{array}{l}\text { Eur- } \\
\text { ope }\end{array}$ & $\begin{array}{l}\text { Catalonia, } \\
\text { Spain }\end{array}$ & $\begin{array}{l}\text { Cfb } \\
\text { Csa } \\
\text { Cfa }\end{array}$ & $\begin{array}{l}1951- \\
2003\end{array}$ & $\begin{array}{l}\text { Annual/ } \\
\text { Season- } \\
\text { al }\end{array}$ & $\begin{array}{l}\text { Turco and } \\
\text { Llasat, } 2011\end{array}$ & $\begin{array}{l}\text { Increase: CDD, PCPTOT } \\
\text { (summer), RX5day (summer). } \\
\text { No temperature indices used. }\end{array}$ \\
\hline $\begin{array}{l}\text { Afr- } \\
\text { ica }\end{array}$ & $\begin{array}{l}\text { South } \\
\text { Africa }\end{array}$ & $\begin{array}{l}\text { Bwh } \\
\text { Bwk } \\
\text { Bsh } \\
\text { Csa } \\
\text { Csb } \\
\text { Cwa } \\
\text { Cwb } \\
\text { Cfa } \\
\text { Cfb } \\
\text { Cfc }\end{array}$ & $\begin{array}{l}1962- \\
2009\end{array}$ & Annual & $\begin{array}{l}\text { Kruger and } \\
\text { Sekele, } 2013\end{array}$ & $\begin{array}{l}\text { Increase: TX90, TXx, TN90p. } \\
\text { No precipitation indices used. }\end{array}$ \\
\hline $\begin{array}{l}\text { Afr- } \\
\text { ica }\end{array}$ & Morocco & $\begin{array}{l}\text { Bwh } \\
\text { Bsh } \\
\text { Bwk } \\
\text { BSk } \\
\text { Csa }\end{array}$ & $\begin{array}{l}1970- \\
2012\end{array}$ & $\begin{array}{l}\text { Annual/ } \\
\text { Season- } \\
\text { al }\end{array}$ & $\begin{array}{l}\text { Filahi et al., } \\
2016\end{array}$ & $\begin{array}{l}\text { Increase: TX90p, TN90p, } \\
\text { SDII (coastal regions). } \\
\text { Decrease: PRCPTOT. }\end{array}$ \\
\hline $\begin{array}{l}\text { Aust- } \\
\text { ralia }\end{array}$ & Australia & $\begin{array}{l}\text { A B C } \\
\text { D }\end{array}$ & $\begin{array}{l}1930- \\
2011\end{array}$ & $\begin{array}{l}\text { Month- } \\
\text { ly }\end{array}$ & $\begin{array}{l}\text { King et al., } \\
2014\end{array}$ & $\begin{array}{l}\text { Increase: Rx5day (single sub- } \\
\text { region). Only Rx5day tested, } \\
\text { no other indices used. }\end{array}$ \\
\hline $\begin{array}{l}\text { South } \\
\text { Ame- } \\
\text { rica }\end{array}$ & $\begin{array}{l}\text { Paraná } \\
\text { River } \\
\text { Basin, } \\
\text { Brazil }\end{array}$ & $\begin{array}{l}\mathrm{Aw} \\
\mathrm{Cfa}\end{array}$ & $\begin{array}{l}1986- \\
2011\end{array}$ & Annual & $\begin{array}{l}\text { Zandonadi } \\
\text { et al., } 2016\end{array}$ & $\begin{array}{l}\text { Increase: R95p, SDII, } \\
\text { R20mm, R10mm, PRCPTOT. } \\
\text { No temperature indices used. }\end{array}$ \\
\hline $\begin{array}{l}\text { South } \\
\text { Ame- } \\
\text { rica }\end{array}$ & $\begin{array}{l}\text { South } \\
\text { America }\end{array}$ & $\begin{array}{l}\text { A B C } \\
\text { D }\end{array}$ & $\begin{array}{l}1950- \\
2010\end{array}$ & Annual & $\begin{array}{l}\text { de los } \\
\text { Milagros } \\
\text { Skansi et al., } \\
2013\end{array}$ & $\begin{array}{l}\text { Increase: TNn, TN90p, } \\
\text { Rx1day, Rx5day, R95p, } \\
\text { PRCPTOT, SDII. } \\
\text { (Precipitation trends are } \\
\text { concentrated in Amazonia and } \\
\text { southeast regions.) }\end{array}$ \\
\hline $\begin{array}{l}\text { North } \\
\text { Ame- } \\
\text { rica }\end{array}$ & $\begin{array}{l}\text { Northeast } \\
\text { US States }\end{array}$ & $\begin{array}{l}\text { Dfb } \\
\text { Dfa }\end{array}$ & $\begin{array}{l}1951- \\
2010\end{array}$ & Annual & $\begin{array}{l}\text { Thibeault } \\
\text { and Seth, } \\
2014\end{array}$ & $\begin{array}{l}\text { Increase: R95p, Rx1day, } \\
\text { Rx5day, CWD. } \\
\text { Decrease: TN10p. }\end{array}$ \\
\hline $\begin{array}{l}\text { North } \\
\text { Ame- } \\
\text { rica }\end{array}$ & $\begin{array}{l}\text { Tlaxcala, } \\
\text { Mexico }\end{array}$ & Cwb & $\begin{array}{l}1952- \\
2003\end{array}$ & $\begin{array}{l}\text { Season- } \\
\text { al }\end{array}$ & $\begin{array}{l}\text { Diaz et al., } \\
2012\end{array}$ & $\begin{array}{l}\text { Increase: FD, SU. } \\
\text { Decrease: TX10p. No } \\
\text { precipitation indices used. }\end{array}$ \\
\hline
\end{tabular}

Table 1. Review of global literature using ETCCDI indices. Index acronym definitions in Appendix. Köppen climate descriptions from maps produced by Peel et al., 2007. 
Considering the fact that most studies cover large geographic areas with multiple climate types, disparate regional results are not surprising, but methods to address this issue are not often used by researchers. Few studies include methods such as field significance that could delineate areas of spatially cohesive trends. Spatial cluster analysis was employed successfully in a study of temperature indices of South Africa, but similar analysis was not noted for any precipitation indices (Kruger and Sekele, 2013). In some studies that cover large regions such as South America and India, division of the region into climatic sub-regions provides a technique for discussing changes to unique precipitation regimes (de los Milagros, 2013; Panda et al., 2016). Many authors offer qualitative interpretations that spatially incoherent trends may relate to coastal or continental weather dynamics. For example, increasing intensity is observed in coastal Morocco and Iran but not central regions (Rahimzadeh, et al., 2009; Filahi et al., 2016). In this review, increased intensity and extremity of precipitation seemed to be concentrated in coastal and tropical climates. However, without consistent spatial analysis of precipitation index results, these observations may not be well supported.

Even without considering non-stationarity of precipitation regimes, finding ways to represent spatial variation of rainfall trends is a scientific challenge. Characterizing the intensity of rainfall in different regions with a consistent methodology is a long standing geographic problem (Martin-Vide, 2004; Oliver, 1980; Horn and Bryson, 1960). Recent studies have visualized precipitation decline and drought duration (Vicente-Serrano et al., 2015). Interpolation of rain fields from rain gages remains an active field of research (Wang et al., 2014; Xu et al., 2015). Contributing to the diversity of approaches used to 
represent the spatial variation of rainfall may be that storm events provide a wealth of characteristics for study. Climatological studies tend to focus on rainfall volume, intensity and extreme event probability, but many other storm properties exist (Jiang et al., 2016). For example, individual storm characteristics such as skewness and kurtosis of storm rainfall can be used to identify different regional convective processes (Brommer et al., 2013). Given that precipitation is an abstract phenomenon that can be examined through different approaches, it is not surprising that global research on precipitation is difficult to synthesize spatially (Karl and Knight, 1998; Frich et al., 2002; Zhang et al., 2011) .

Temporal scale is another important feature in the study of precipitation, and current ETCCDI methodology does not dictate multiple scales of analysis. The RClimDex software widely employed by researchers to calculate ETCCDI indices assumes the period of study is annual in most cases, although monthly calculations are available for some indices (Zhang and Yang, 2004). Many researchers have opted to conduct research on an annual or seasonal basis, and a few have used monthly (Table 1). Further, ETCCDI indices are based on the use of daily precipitation and temperature data. Considering that modern precipitation research can now look at real-time rain rates through innovations in remote sensing and computation, the use of the daily scale may be limiting (Munoz et al., 2015; Sanò et al., 2015). Further, the use of daily records obscures the fact that precipitation is a phenomenon occurring at a sub-daily scale (Trenberth, 1998). One reason for the use of daily data is that the ETCCDI indices are designed to emphasize global collaboration, and high resolution records are not available 
in many regions (Peterson and Manton, 2008). Further, ETCCDI indices are not only used for historic analysis but also for future projections made by global climate models. Making projections at the daily scale is a vast improvement upon earlier climate models that were limited to changes occurring at the decadal scale (Houghton et al., 1990). Although the resolution of climate models steadily increases, the ability of these models to deliver precipitation projections that resemble realistic precipitation at the hourly scale remain novel (Xu et al., 2005; Seneviratne et al. 2006; Prein et al., 2016). However, the reliance on daily data provides a potential obstacle to detection of trends (Cooley and Chang, 2017). It is possible that the use annual time scales and daily data may contribute to the incoherent precipitation trends observed.

\subsection{Pacific Northwest Climate}

The atmospheric dynamics that lead to precipitation in the Pacific Northwest are expected to be altered by climate change (Chou et al., 2012). The results of this include an intensification of convergence zones like the North Pacific storm track that transport water vapor to the Pacific Northwest (Houghton et al., 1990; Salathé, 2006). Atmospheric rivers that are responsible for many of the flood events in the region are also anticipated to increase (Dettinger, 2011). Regional climate models indicate increased magnitude of single day rainfall events in the $21^{\text {st }}$ century (Salathé et al., 2014). Elevation increase of snow lines may contribute to increased precipitation if a greater portion of moisture falls as rain rather than snow (Tohver et al., 2014). Annual precipitation has increased in the region over the twentieth century although whether this is attributable to climate change is debatable (Mote, 2003a; Dore, 2005). The seasonal distribution of the increased 
precipitation from climate change is expected to occur in winter, but most observed significant increasing trends are in spring (Abatzoglou et al., 2014).

Climate models indicate different modes of precipitation change for northern and southern areas of North America, and since the Pacific Northwest lies between these areas the nature of changes is uncertain. Global climate models predict annual mean precipitation changes of $-10 \%$ to $20 \%$ by the 2080 s in the Pacific Northwest (Mote, 2003a; Salathé, 2006; Mote and Salathé, 2010). The seasonal distribution of precipitation is likely to skew towards winter months with summers becoming drier. Rates of regional annual mean temperature warming are anticipated at $.1^{\circ} \mathrm{C}$ to $.6^{\circ} \mathrm{C}$ per decade in the future. Changes in atmospheric temperature drive how much water vapor can be held in the air without precipitation. As atmospheric temperatures rise, the amount of water vapor that can be held without precipitation increases at a rate of $7 \%$ per degree Celsius (Huntington, 2006). For this reason, summers are likely to become drier. Increased water vapor transport in winter, may cause more intense rain events (Berg et al., 2009). Temperature variation and its associated effect on evaporation and moisture transport will play a large role in future Northwest climate.

Although a number of studies have been performed regarding long-term climate change in the Northwest, hydrologic studies of observational records have tended to focus on streamflow, snowpack, and modes of climate variability. Declining trends in snowpack and changes to streamflow timing associated with higher temperatures have been observed (Lundquist and Cayan, 2002; Mote, 2003b; Luce and Holden, 2009). Early spring streamflow has increased while late fall streamflow has declined with changes in 
the timing of snowmelt and increased evapotranspiration in summer (Chang et al., 2012). El Nino and the Pacific Decadal Oscillation have been shown to have an important influence over temperature but only moderate influences on precipitation (Redmond and Koch, 1991; Praskievicz and Chang, 2009).

A number of recent studies of precipitation have been conducted in British Columbia. Predictions of increased winter rainfall and decreased summer rainfall have not yet been born out in studies of observational records (Burn and Taleghani, 2013). Instead, increased frequency of heavy precipitation events in summer have been observed while winter has mixed signals. Some indication of increased intensity in spring has also been observed (Jakob et al., 2003). The nature and direction of trends is different across sub-regions, suggesting that different convective processes are creating diverse precipitation response. Looking at the spatial extent of extreme precipitation in the Pacific Northwest, heterogeneous topography was found to be a key limiting factor on the spatial extent of extreme rainfall (Parker and Abatzoglou, 2016). For this reason, closely related areas with different topography may have different responses to climate change, suggesting the need for a spatially explicit analysis. 


\section{Chapter 3. Methods}

\subsection{Study Area}

The City of Portland is selected as the area of study because of an interest in exploring changes to rainfall in temperate convergence zones, and the availability of a high resolution rainfall gage network in the city. The city is located $129 \mathrm{~km}$ east of the Pacific Ocean in the lower Pacific Northwest, near the $45^{\text {th }}$ parallel in the Northern Hemisphere (Figure 1). The Köppen-Geiger climate map describes it as a "Csb" climate; temperate with warm, dry summers (Peel et al., 2007). Moisture is transported to the area through the North Pacific storm track (Dart and Johnson, 1981). Regional precipitation distribution is highly variable and driven by complex topography and orographic lift (Salathé, 2003). Portland is located in a low lying area between the Coastal and Cascade mountain ranges and therefore receives relatively lower precipitation, around $930 \mathrm{~mm}$ of rain annually (based on years 1981-2010) (Chang et al, 2007).

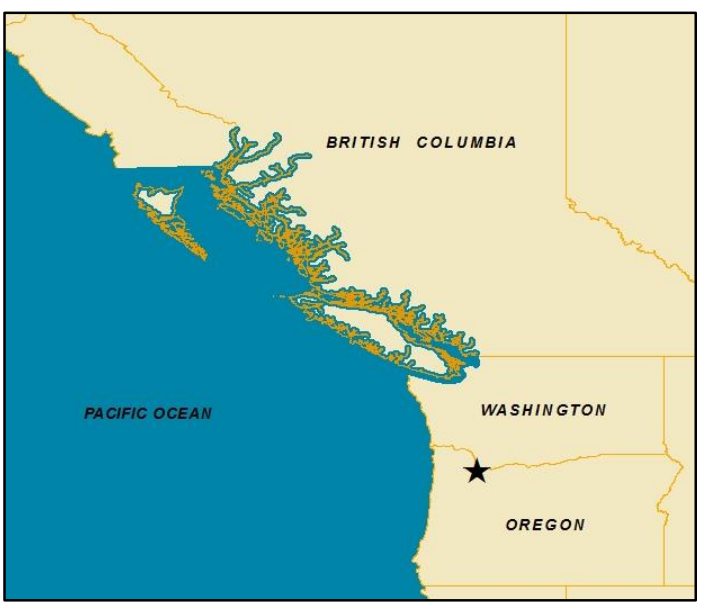

Figure 1. Pacific Northwest regional map. Study area designated with star. 


\subsection{Data}

The data types and sources used are provided in Table 2. We used 5-minute precipitation records from five rain gage stations in the City of Portland Hydrological Data Retrieval and Alarm (HYDRA) network with data from 1977-2016. Records begin January 1, 1977 and end December 31, 2016. Data coverage is 95\% complete. Figure 2 describes the location of these five rain gages. Data were transformed from inches to $\mathrm{mm}$. Using Pandas package from Rv3.1.1 the data are summarized at the daily and hourly scale (0:00 - 23:59) PST resolution (R Core Team, 2014). Inspection of data quality was performed visually by graphing time series data and looking for outliers.

\begin{tabular}{|l|l|l|l|l|}
\hline Data Type & Detail & Source & Status & Dates \\
\hline Rainfall & $\begin{array}{l}\text { Hourly \& } \\
\text { Daily }\end{array}$ & City of Portland & Observed & $1977-2016$ \\
\hline $\begin{array}{l}\text { Surface } \\
\text { Temperature } \\
\text { Max }\end{array}$ & Daily Min \& & NOAA & Observed & $1977-2016$ \\
\hline $\begin{array}{l}\text { Atmosphere } \\
\text { (700mB) }\end{array}$ & Daily & NOAA & Observed & $1977-2016$ \\
\hline $\begin{array}{l}\text { Stream } \\
\text { Discharge }\end{array}$ & Daily & USGS & Observed & $1977-2016$ \\
\hline Rainfall & Daily & $\begin{array}{l}\text { CMIP5 } \\
\text { models:CanESM2, } \\
\text { CESM1-CAM5, } \\
\text { CNRM-CM5 }\end{array}$ & Models & $1977-2005 ;$ \\
$2006-2100$
\end{tabular}

Table 2. Data types and sources 


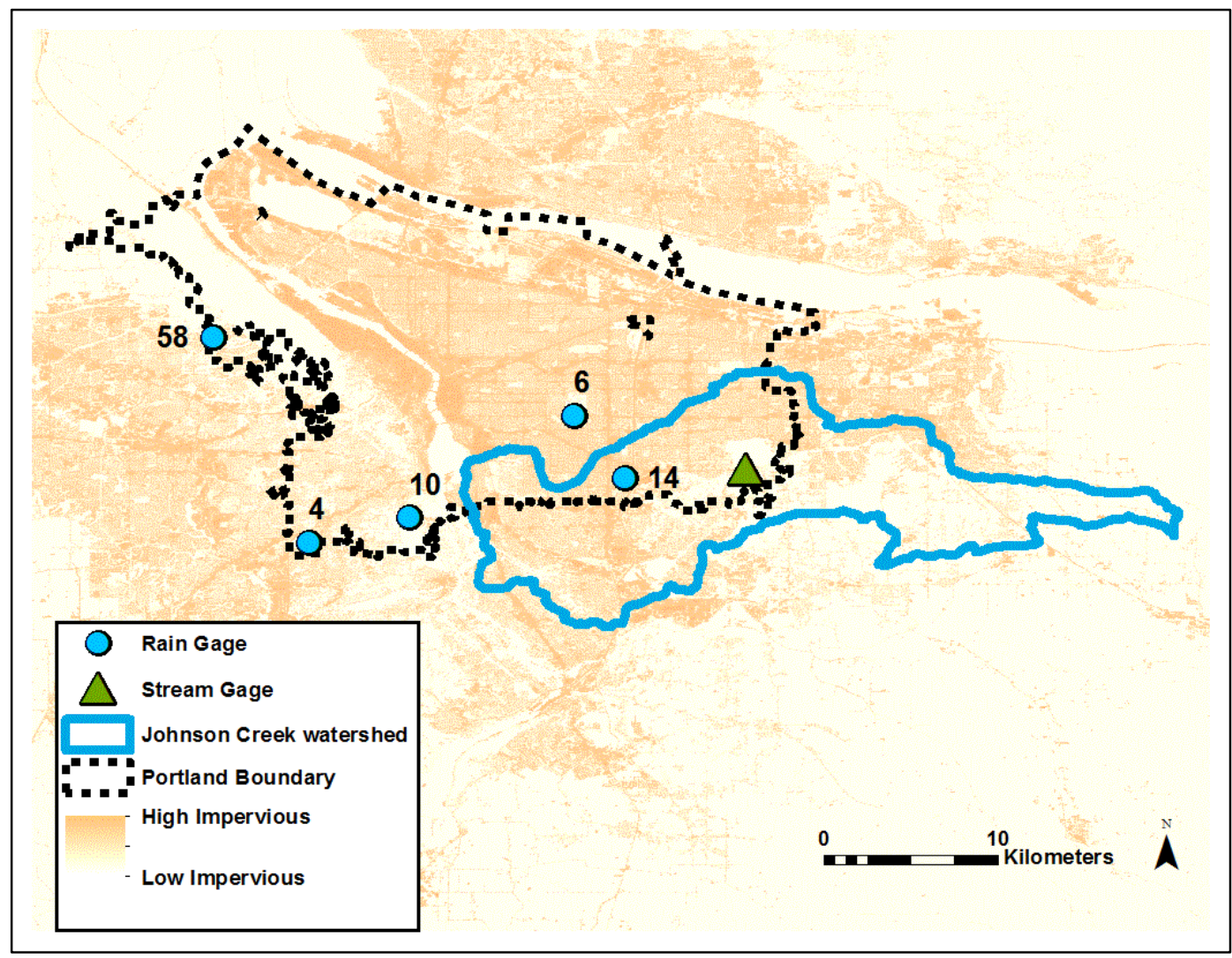

Figure 2. Study area detail map

From the CMIP5 multi-model ensemble three global climate models were selected including CanESM2, CESM1-CAM5, CNRM-CM5 (Taylor et al., 2012). Table 3 shows the models and institutions responsible for model development. Models selection was based on superior performance projecting accurate spatial and historic precipitation conditions in the Pacific Northwest during the $20^{\text {th }}$ century (Rupp et al., 2013). For each model, downscaled precipitation projections were obtained from the CMIP5 Climate and Hydrology Projections using the LOCA (Localized Constructed Analogs) archive at http://gdo-dcp.ucllnl.org/downscaled_cmip_projections (Pierce et al., 2014). LOCA 
downscaling improves global climate model $1^{\circ} \times 1^{\circ}$ horizontal latitude-longitude grid resolution to $1 / 16^{\circ} \times 1 / 16^{\circ}$ horizontal latitude-longitude grid resolution (Pierce et al., 2014). A single Portland, OR grid point at $45.523 \mathrm{~N},-122.677 \mathrm{~W}$ was selected and historic projections for 1977-2005 and future projections for 2006-2100 were obtained. The Representative Concentration Pathway (RCP) 8.5 high emissions scenario is selected because it represents the upper bounds of greenhouse gas concentration and emission. This scenario represents a future with a global population of 12 billion in 2100, where minimal gains in the deployment of energy efficiencies occur (Riahi et al., 2011).

\begin{tabular}{|l|l|l|}
\hline \multicolumn{1}{|c|}{ Model Name } & \multicolumn{1}{c|}{ Institute ID } & \multicolumn{1}{c|}{ Modeling Center } \\
\hline CanESM2 & CCCMA & $\begin{array}{l}\text { Canadian Centre for Climate Modelling and } \\
\text { Analysis }\end{array}$ \\
\hline CESM1-CAM5 & NSF-DOE-NCAR & Community Earth System Model Contributors \\
\hline CNRM-CM5 & CNRM-CERFACS & $\begin{array}{l}\text { Centre National de Recherches } \\
\text { Météorologiques / Centre Européen de } \\
\text { Recherche et Formation Avancée en Calcul } \\
\text { Scientifique }\end{array}$ \\
\hline
\end{tabular}

Table 3. Global climate models used and creator

Daily streamflow data from USGS for Johnson Creek Sycamore Station \#14211500 from 1977-2016 was used (http://waterdata.usgs.gov/nwis/sw). The station was chosen because it has a long-term discharge record, and high flows are indicative of creek flood events (Chang et al., 2010; Ahilan et al., 2016). Although this station is not located within the City of Portland, precipitation from the HYDRA network were used to approximate rainfall that contributes to discharge at Sycamore station.

Temperature records were acquired from National Climatic Data Center (NCDC) Station 356751 located at Portland International Airport (PDX). Daily maximum and minimum surface temperature are acquired for 1977-2016. Data is 100\% complete. 
Atmospheric soundings from National Ocean and Atmospheric Administration (NOAA) for temperature at $700 \mathrm{mb}$ were acquired from the Salem, OR National Weather Service (NWS) station KLME, USM00072694. A daily record of multiple sub-daily soundings was acquired for 1977-2016. In order to create a daily record from the subdaily soundings, records made at 12:00 PST were used (94\% of population). When soundings were not available at $12 \mathrm{~h}$, soundings from earlier in the morning were used where possible (5\%). The distribution of sounding recording time is shown in Table 4.

\begin{tabular}{|l|l|}
\hline \multicolumn{2}{|l|}{ Distribution of sounding recording time on 24 h clock } \\
\hline Before 12:00 (<12:00) & $5.69 \%$ \\
\hline $12: 00$ & $93.9 \%$ \\
\hline After 12:00 (>12:00) & $.004 \%$ \\
\hline Missing (NA) & $.34 \%$ \\
\hline
\end{tabular}

Table 4. Recording time of atmospheric soundings

\subsection{Methods for Question 1: Comparisons with downscaled climate models}

Select ETCCDI precipitation indices that can measure heavy and extreme rainfall were chosen for use in this study based on the expectation that they can measure changes to the hydrologic cycle in response to climate change (Giorgi et al., 2011; Giorgi et al., 2014). These indices include the following: simple daily intensity (SDII), maximum consecutive dry days (CDD), maximum consecutive wet days (CWD), and total precipitation above the $95^{\text {th }}$ percentile base period distribution (R95p). Table 5 present the equations for these as defined by ETCCDI. Giorgi et al. (2014) predicted that in response to climate change consecutive wet days would decrease as rainfall became more 
intense. Indices SDII, R95p, and CDD are expected to increase. Figure 3 describes the hypothesis about future state of these variables at the global scale.

\begin{tabular}{|c|c|c|}
\hline Indicator & Definition & Equation \\
\hline CDD & $\begin{array}{l}\text { Maximum length of dry spell, maximum number of } \\
\text { consecutive days with RR }<1 \mathrm{~mm} \text { : Let RRij be the daily } \\
\text { precipitation amount on day } \mathrm{i} \text { in period } \mathrm{j} \text {. Count the largest } \\
\text { number of consecutive days where: } \\
R R_{i j}<1 \mathrm{~mm}\end{array}$ & Equation 1 \\
\hline CWD & $\begin{array}{l}\text { Maximum length of wet spell, maximum number of } \\
\text { consecutive days with } R R \geq 1 \mathrm{~mm} \text { : Let } R R_{\mathrm{ij}} \text { be the daily } \\
\text { precipitation amount on day } \mathrm{i} \text { in period } \mathrm{j} \text {. Count the largest } \\
\text { number of consecutive days where: } \\
R R_{i j} \geq 1 \mathrm{~mm}\end{array}$ & Equation 2 \\
\hline R95p & $\begin{array}{l}\text { Annual total PRCP when } \mathrm{RR}>95 \mathrm{p} \text {. Let } \mathrm{RR}_{\mathrm{wj}} \text { be the daily } \\
\text { precipitation amount on a wet day } \mathrm{w}(\mathrm{RR} \geq 1.0 \mathrm{~mm}) \text { in } \\
\text { period } \mathrm{i} \text { and let } \mathrm{RR}_{\mathrm{wn}} 95 \text { be the } 95^{\text {th }} \text { percentile of precipitation } \\
\text { on wet days in the } 1961-1990 \text { period. If } \mathrm{W} \text { represents the } \\
\text { number of wet days in the period, then: } \\
R 95 p_{j}=\sum_{w=1}^{W} R R_{w j} \text { where } R R_{w j}>R R_{w n} 95\end{array}$ & Equation 3 \\
\hline SDII & $\begin{array}{l}\text { Simple precipitation intensity index: } L e t R_{\mathrm{wj}} \text { be the daily } \\
\text { precipitation amount on wet days, } \mathrm{w}(\mathrm{RR} \geq 1 \mathrm{~mm}) \text { in } \\
\text { period j. If } \mathrm{W} \text { represents number of wet days in } \mathrm{j} \text {, then: } \\
S D I I_{j}=\frac{\sum_{w=1}^{W} R R_{w j}}{W}\end{array}$ & Equation 4 \\
\hline
\end{tabular}

Table 5. Definition of ETCCDI indices used for Research Question 1 (Karl et al., 1999; Peterson et al., 2001)

The indices presented in Table 5 were generated for each of the five Portland, OR rainfall stations spanning 1977-2005. The observed time series is shortened in this section to facilitate comparison with model simulation dates. The indices were generated from projections from the three LOCA downscaled global climate models (CanESM2, CESM1-CAM5, CNRM-CM5) historic (1977-2005) and future (2006-2100) periods for emissions scenarios RCP 8.5. 


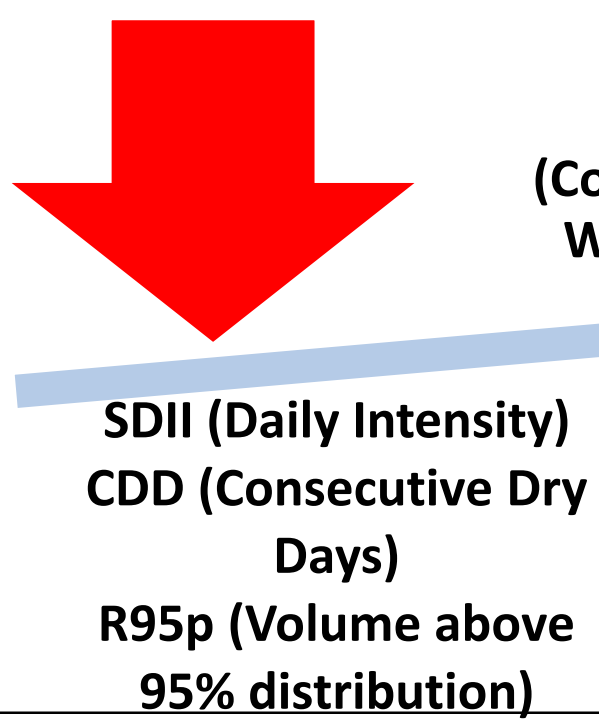

CWD (Consecutive Wet Days)

Figure 3. Expected change to ETCCDI indices for 2006-2100 (Giorgi et al. 2014).

The RClimDex software created by ETCCDI was used to generate the selected indices (Zhang and Yang, 2004). The RClimDex software is designed to run parallel to the statistical software R. Input climate variables to the RClimDex software include daily precipitation, maximum temperature, and minimum temperature. The software uses these inputs to generate a unique index value for every year of the study.

In order to detect change to each index over time, trend detection is required and the Mann-Kendall rank-based correlation test was selected for this purpose. The MannKendall test generates a tau and p-value to measure if there is a significant monotonic increase or decrease in a variable over time (Mann, 1941). The tau value ranges between $(-1,1)$, and negative values indicate decreasing trends and positive values increasing trends. The significance level selected for this test was $10 \%(.1)$ and $5 \%(.05)$. The null hypothesis where p-value >.1 indicates no significant monotonic trend exists. This test is 
appropriate for time series data that are not normally distributed and was the preferred test of other researchers employing ETCCDI methods (Dumitrescu et al., 2015; Filahi et al., 2016). The test was performed using Rv3.1.1 package "Kendall" (Mcleod, 2005).

In order to satisfy the assumption of the Mann-Kendall test that data be independent, the indices were tested for autocorrelation. Test of autocorrelation were completed using the partial autocorrelation function in $\mathrm{R}$. Where autocorrelation was present, tau values were bootstrapped using the R package "boot" which includes bootstrapping functions for autocorrelated time series data (Davison and Hinkley, 1997; Canty and Ripley, 2012). This test provides a mean tau value as generated by 500 instances of the Mann-Kendall function.

\subsection{Methods for Question 2: Comparing annual and monthly trends}

Comparing indices across different temporal scales can help understand the limitations or benefits of the annual scale of analysis. By investigating the monthly scale we have a higher resolution picture of what is happening to precipitation and temperature. A number of precipitation indices are examined at the annual and monthly scale. Indices selected are shown in Table 6, including total precipitation (PRCPTOT), simple daily and hourly intensity (SDII), maximum 1day event (Rx1day), maximum 5 day event (Rx5day), maximum temperature (TXx), and minimum temperature (TNn). The index of maximum 5 day precipitation (Rx5day) is theorized to be the most useful for flood risk (Frich et al. 2002). 


\begin{tabular}{|c|c|c|}
\hline Indicator & Definition & Equation \\
\hline PRCPTOT & $\begin{array}{l}\text { Annual total precipitation in wet days: } \\
\text { Let } R R_{\mathrm{ij}} \text { be the daily precipitation amount on } \\
\text { day } \mathrm{i} \text { in period } \mathrm{j} \text {. If I represents the number of } \\
\text { days in } \mathrm{j} \text {, then } \\
\text { PRCPTOT }=\sum_{i=1}^{I} R R i j\end{array}$ & Equation 5 \\
\hline Rx1day & $\begin{array}{l}\text { Monthly maximum 1-day precipitation: } \\
\text { Let } \mathrm{RR}_{\mathrm{ij}} \text { be the daily precipitation amount on } \\
\text { day } \mathrm{i} \text { in period } \mathrm{j} \text {. The maximum 1-day value for } \\
\text { period } \mathrm{j} \text { are: } \\
R x 1 \text { day }_{j}=\max \left(R R_{i j}\right)\end{array}$ & Equation 6 \\
\hline Rx5day & $\begin{array}{l}\text { Monthly maximum consecutive } 5 \text {-day } \\
\text { precipitation: Let } R R_{k j} \text { be the precipitation } \\
\text { amount for the 5-day interval ending } \mathrm{k} \text {, period } \mathrm{j} \text {. } \\
\text { Then maximum 5-day values for period } \mathrm{j} \text { are: } \\
R x 5 \text { day }_{j}=\max \left(R R_{k j}\right)\end{array}$ & Equation 7 \\
\hline SDII & $\begin{array}{l}\text { Simple precipitation intensity index: } \\
\text { Let } R R_{w j} \text { be the daily precipitation amount on } \\
\text { wet days, } \mathrm{W}(\mathrm{RR} \geq 1 \mathrm{~mm}) \text { in period } \mathrm{j} \text {. } \\
\text { If } \mathrm{W} \text { represents number of wet days in } \mathrm{j} \text {, then: } \\
S D I I_{j}=\frac{\sum_{w=1}^{W} R R_{w j}}{W}\end{array}$ & Equation 4 \\
\hline $\begin{array}{l}\text { SDII } \\
\text { (Hourly) }\end{array}$ & $\begin{array}{l}\text { Hourly simple precipitation intensity index: } \\
\text { Let } R R_{w j} \text { be the daily precipitation amount on } \\
\text { wet days, } \mathrm{w}(\mathrm{RR} \geq 1 \mathrm{~mm}) \text { in period } \mathrm{j} \text {. } \\
\text { If } \mathrm{H} \text { represents number of wet hours in } \mathrm{j} \text {, } \\
S D I I_{j}=\frac{\sum_{w=1}^{W} R R_{w j}}{H}\end{array}$ & Equation 8 \\
\hline
\end{tabular}




\begin{tabular}{|c|c|c|}
\hline Indicator & Definition & Equation \\
\hline $\mathrm{TXx}$ & $\begin{array}{l}\text { Monthly maximum value of daily maximum } \\
\text { temperature: Let } T X_{x} \text { be the daily maximum } \\
\text { temperatures in month } \mathrm{k} \text {, period } \mathrm{j} \text {. The } \\
\text { maximum daily maximum temperature each } \\
\text { month is then: } \\
T X_{x k j}=\max \left(T X_{x k j}\right)\end{array}$ & Equation 9 \\
\hline $\mathrm{TNn}$ & $\begin{array}{l}\text { Monthly minimum value of daily minimum } \\
\text { temperature: Let } \mathrm{TN}_{\mathrm{n}} \text { be the daily minimum } \\
\text { temperatures in month } \mathrm{k} \text {, period } \mathrm{j} \text {. The } \\
\text { minimum daily minimum temperature each } \\
\text { month is then: } \\
T N_{n k j}=\min \left(T N_{n k j}\right)\end{array}$ & Equation 10 \\
\hline
\end{tabular}

Table 6. Definition of ETCCDI indices used for Research Question 2. (Karl et al., 1999; Peterson et al., 2001)

RClimDex is used to extract indices of interest at the monthly scale where available. The indices calculated at the monthly scale by RClimDex include PRCPTOT, Rx1day, Rx5day, TXx, and TNn. The process of running RClimDex is described in the methodology of Question 1.

It was of interest to include SDII in the monthly analysis as another variable important for flooding. This variable is not available at the monthly scale by RClimDex and required manual calculation in Rv3.1.1 (R Core Team, 2014). The ETCCDI formula for SDII uses daily rainfall totals, and the equation is given in Equation 4. Since we are interested in trend detection at the monthly scale, it was also of interest to take advantage of the high resolution data and also calculate SDII using hourly rainfall total as shown in Equation 8. Two calculations of SDII were therefore performed, SDII at the daily scale and SDII at the hourly scale using the following calculations: 
To compute SDII at the daily scale, let $R R_{w j}$ be the daily precipitation amount on wet days, $w(R R \geq 1 \mathrm{~mm})$ in period $j$. If $W$ represents number of wet days in $j$,

$S D I I_{j}=\frac{\sum_{w=1}^{W} R R_{w j}}{W}$ Equation 4

To compute SDII at the hourly scale, let $R R_{w j}$ be the daily precipitation amount on wet days, $w(R R \geq 1 \mathrm{~mm})$ in period $j$. If $H$ represents number of wet hours in $j$,

$S D I I_{j}=\frac{\sum_{w=1}^{W} R R_{w j}}{H}$ Equation 8

The number of trends detected at the annual scale is compared with those detected

at the monthly scale. All trends are analyzed with the Mann-Kendall and bootstrapping approach described in Question 1 methods. The null hypothesis of trend tests is that no monotonic trends exist.

In order to consider possible mechanisms leading to observed trends in climate indices, monthly atmospheric soundings for temperature at $700 \mathrm{mb}$ are used and examined overtime. Surface temperatures are unlikely to correspond well with precipitation, and for this reason atmospheric temperatures as $700 \mathrm{mb}$ were selected. Although there is not a diurnal cycle at $700 \mathrm{mb}$, maximum and minimum monthly values are used for this research in place of means, so that actual variability is maintained and ETCCDI indices methods for TNn and TXx ETCCDI can be used. Trends in these variables are also calculated with Mann-Kendall.

\subsection{Methods for Question 3: ETCCDI Indices and Peak Streamflow}

To better understand the relationship between Portland precipitation and discharge that contributes to flooding, the monthly ETCCDI climate indices are 
correlated with stream discharge records at Johnson Creek, Sycamore Station \#14211500. Analysis is conducted on the 40 largest discharge events in Johnson Creek.

Maximum peak flow events used in the analysis are selected by sorting all daily Sycamore Station discharge records for 1977-2016 and finding the 40 largest flow events. Where multiple maximum events occur in a single month, the largest value from the month was used and other lower maximums in that month were removed from the list. This ensured that only one peak discharge record could exist for a given month, and helps to ensure that events are independent. This resulted in 40 maximum events with unique year-month combinations.

Climate indices for the months when these maximum events occurred will be combined with peak discharge event records to create a single precipitation-discharge record. This record consists of multiple variables (discharge, SDII, SDII_hourly, Rx1day, Rx5day, PRCPTOT).

Kendall's rank based correlation test will then be used to detect the strength of the correlations between the ETCCDI indices and peak streamflow discharge (Bracken et al., 2008). The Kendall test is used rather than the Mann-Kendall because Mann-Kendall is only appropriate for continuous time series data. The Kendall test will measure the strength of correlation between variables on a scale of $(-1,1)$ with 1 representing perfect correlation. Data are tested for temporal correlation using R's partial autocorrelation function, and autocorrelated data will use addressed with bootstrapping. 


\section{Chapter 4. Results}

\subsection{Results for Question 1: Comparisons with downscaled global climate models}

No significant trends in Portland station records for 1977-2005 were found in precipitation indicators including consecutive dry days (CDD), consecutive wet days (CWD), heavy precipitation (R95p), or daily intensity (SDII). As shown in Figure 4 (a), there are no significant trends in any of the stations with mixed signals of increasing or decreasing signals across stations.

Consistent with the Portland observational record, few significant trends were detected in the selected precipitation indices using historic projections for 1977-2005 from three LOCA downscaled global climate models. Results from trend analysis of projections from CanESM2, CESM1- CAM5, and CPMR-CM5 are shown in Figure 4. Only one significantly increasing trend in daily intensity (SDII) was detected amongst models in CPMR-CM5 (tau=.30, p-value= .03). The CESM1-CAM5 model has all nonsignificant increasing trends in the select indices. The models CanESM2 and CPMRCM5 are comparable to analysis of observed data showing non-significant mixed increasing and decreasing trends in the precipitation indices.

Trends from global climate models of projected precipitation under the RCP 8.5 high emissions concentrations for 2006-2100 are consistent with predictions that future rainfall will be more intense as shown in Figure 5. Index trends from the CanESM2 and CNRM-CM5 models show significant increased heavy events (R95p) and daily intensity (SDII) (Giorgi et al., 2014). The CESM1-CAM5 model has positive trends in both these 
variables but they are not statistically significant. The index R95p is just beyond the .1 significance threshold in the CESM1-CAM5 model (tau=.11, p-value=.13).

Observation for all stations 1977-2005
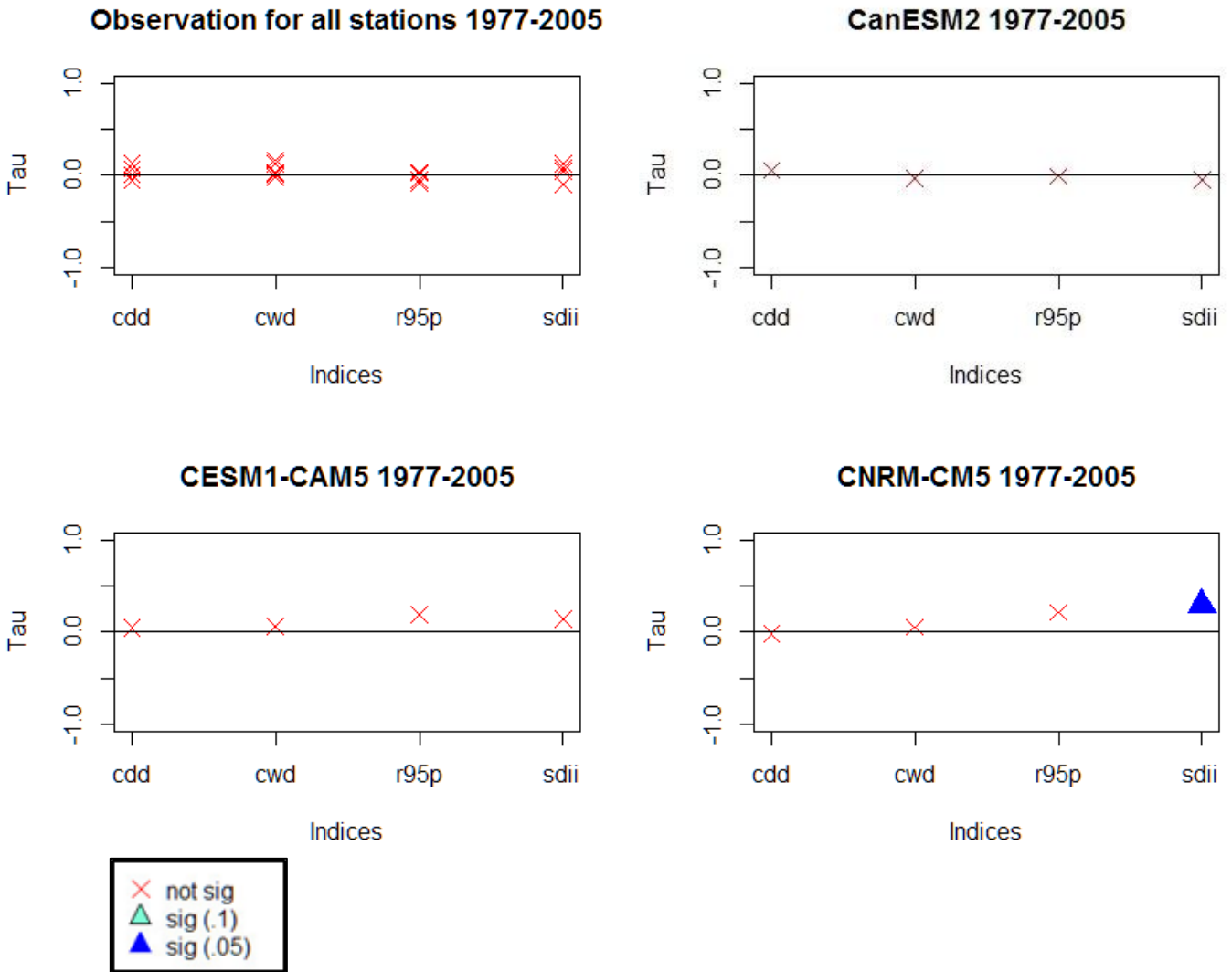

Figure 4. Index trends from observations and climate models for 1977-2005 including CDD, CWD, R95p, SDII. Graphs show consecutive dry days (CDD), consecutive wet days (CWD), rainfall above $95^{\text {th }}$ percentile (R95p) and simple daily intensity (SDII). 
CanESM2 2006-2100

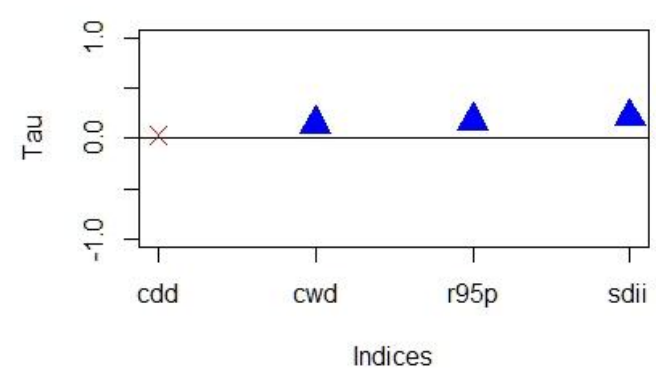

CESM1-CAM5 2006-2100

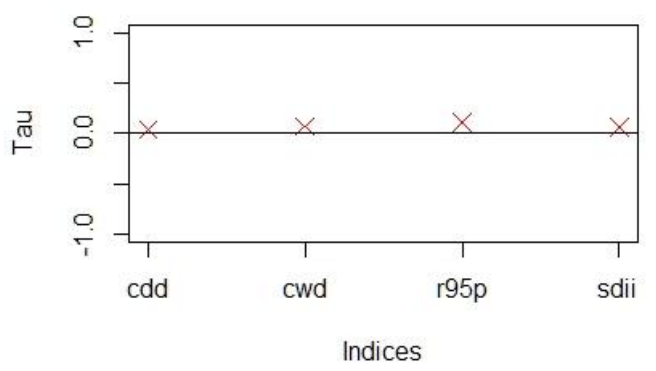

CNRM-CM5 2006-2100

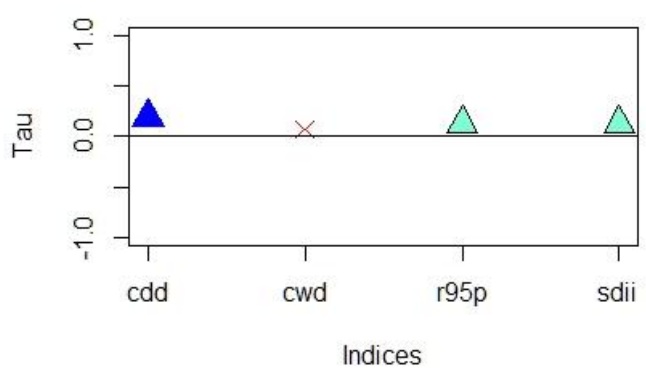

$\times$ not sig

$\triangle \operatorname{sig}(.1)$

$\mathbf{\Delta} \operatorname{sig}(.05)$

Figure 5. Annual index trends from climate models for 2006-2100 including CDD, CWD, R95p, SDII. Indices represent consecutive dry days (CDD), consecutive wet days (CWD), rainfall above 95th percentile (R95p) and simple daily intensity (SDII).

The expected increase in consecutive dry days (CDD) was significantly observed only in the CNRM-CM5 model for years 2006-2100 (tau $=.19$, p-value=.01). Trends are positive but not-significant in other models CESM1-CAM5 and CanESM2 (Giorgi et al., 2014).

Similar results are found for the consecutive wet days (CWD) indicator. A significant increase in consecutive wet days for years 2006-2100 was detected by the CanESM2 model (tau=.15, $\mathrm{p}$-value=.04). Trends are positive but non-significant in other models CESM1-CAM5 and CNRM-CM5.

Only one significant trend in daily intensity is found using historic projections and observations from 1977-2005. Historic projections and observations show non-significant 
mixed direction trends. Multiple trends showing increased precipitation intensity are found using future projections for 2006-2100. As shown in Table 7, trends from these projections are uniformly positive but not uniformly significant.

\begin{tabular}{|c|c|c|c|c|c|c|c|}
\hline & $\begin{array}{l}\text { CanESM2 } \\
1977- \\
2005\end{array}$ & $\begin{array}{l}\text { CESM1- } \\
\text { CAM5 } \\
1977- \\
2005\end{array}$ & $\begin{array}{l}\text { CNRM- } \\
\text { CM5 } \\
1977- \\
2005\end{array}$ & $\begin{array}{c}\text { Observed } \\
\text { Portland, } \\
\text { OR 1977- } \\
2005\end{array}$ & $\begin{array}{l}\text { CanESM2 } \\
\text { R8.5 } \\
2006- \\
2100\end{array}$ & $\begin{array}{l}\text { CESM1- } \\
\text { CAM5 } \\
\text { R8.5 } \\
2006- \\
2100\end{array}$ & $\begin{array}{l}\text { CNRM- } \\
\text { CM5 } \\
\text { R8.5 } \\
2006- \\
2100\end{array}$ \\
\hline CDD & + & + & - & $+/-$ & + & + & $+^{*}$ \\
\hline CWD & - & + & + & $+/-$ & $t^{*}$ & + & + \\
\hline R95Tot & - & + & + & $+/-$ & $t^{*}$ & + & $+^{*}$ \\
\hline SDII & - & + & $+^{*}$ & $+/-$ & $t^{*}$ & + & $+^{*}$ \\
\hline
\end{tabular}

Table 7. Comparison of annual index trends for 1977-2005 and 2006-2100. * indicates significant at $.1,+/-$ indicates mixed direction trends.

\subsection{Results for Question 2: Comparing annual and monthly trends}

Analysis of annual indices PRCPTOT, Rx1day, Rx5day, and SDII indicate consistent increasing trends observed in only PRCPTOT, but no other precipitation indices (Figure 6). Temperature minimum index TNn is increasing and barely nonsignificant $($ tau $=.18, \mathrm{p}$-value $=.12)$. Temperature maximum index TXx is nonsignificantly decreasing (tau=-.12, p-value $=.28)$. 


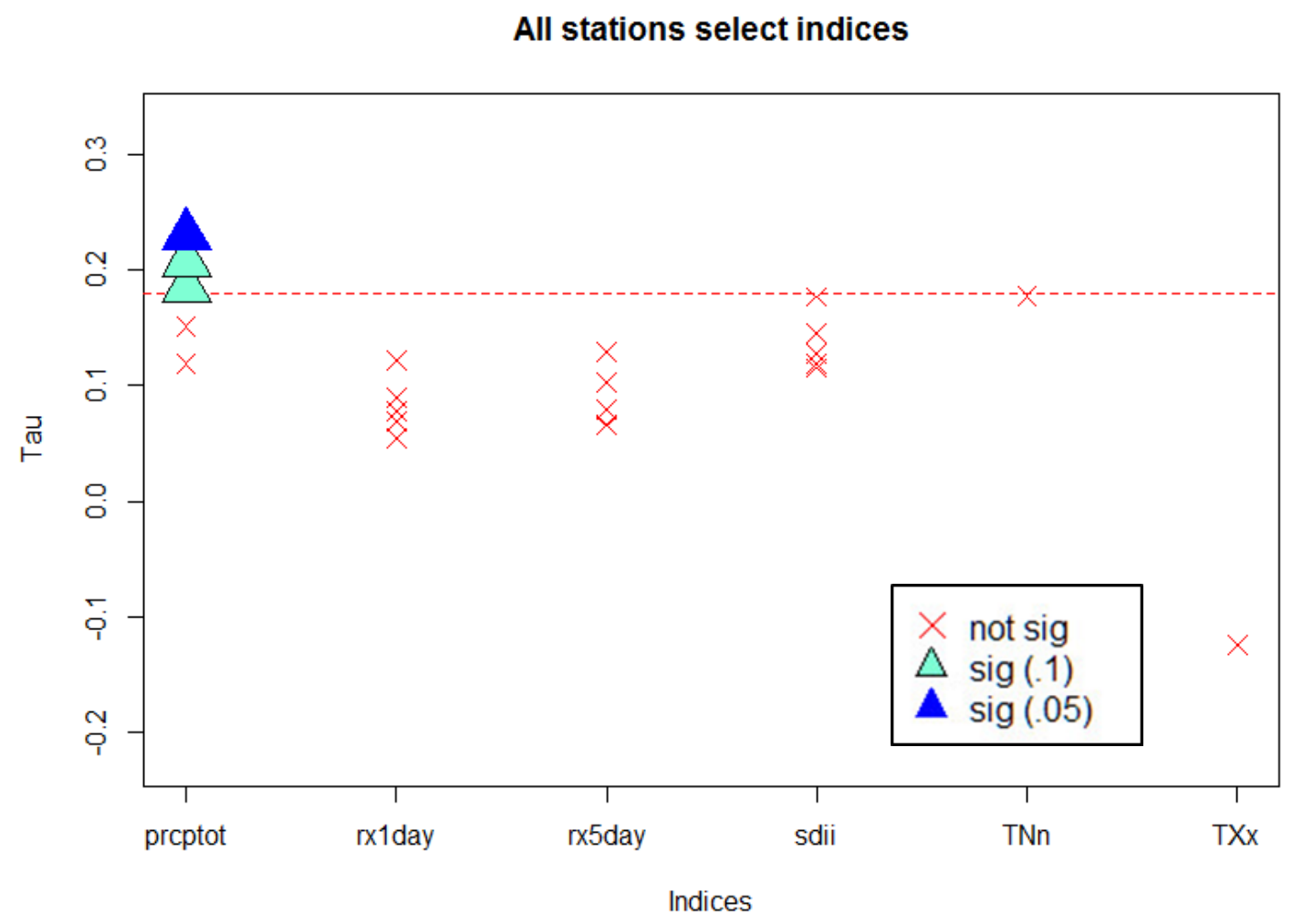

Figure 6. Annual index trends for Portland, OR observations for 1977-2016 including PRCPTOT, Rx1day, Rx5day, SDII, TNn, TXx. Indices represent total rain (PRCPTOT), single day rain (Rx1day), 5 day rain (Rx5day), daily intensity (SDII), temperature minimum (TNn), and temperature maximum (TXx).

When examining precipitation indices on the monthly scale, a different picture emerges and there are many more significant trends identified than on the annual scale analysis. Rx1day is increasing and significant in January and March at the 5\% significance level. Rx5day is increasing and significant in January, February, March and June at the $10 \%$ significance level. PRCPTOT is significant in March, October, and November at 5\% significance (Figure 7). 

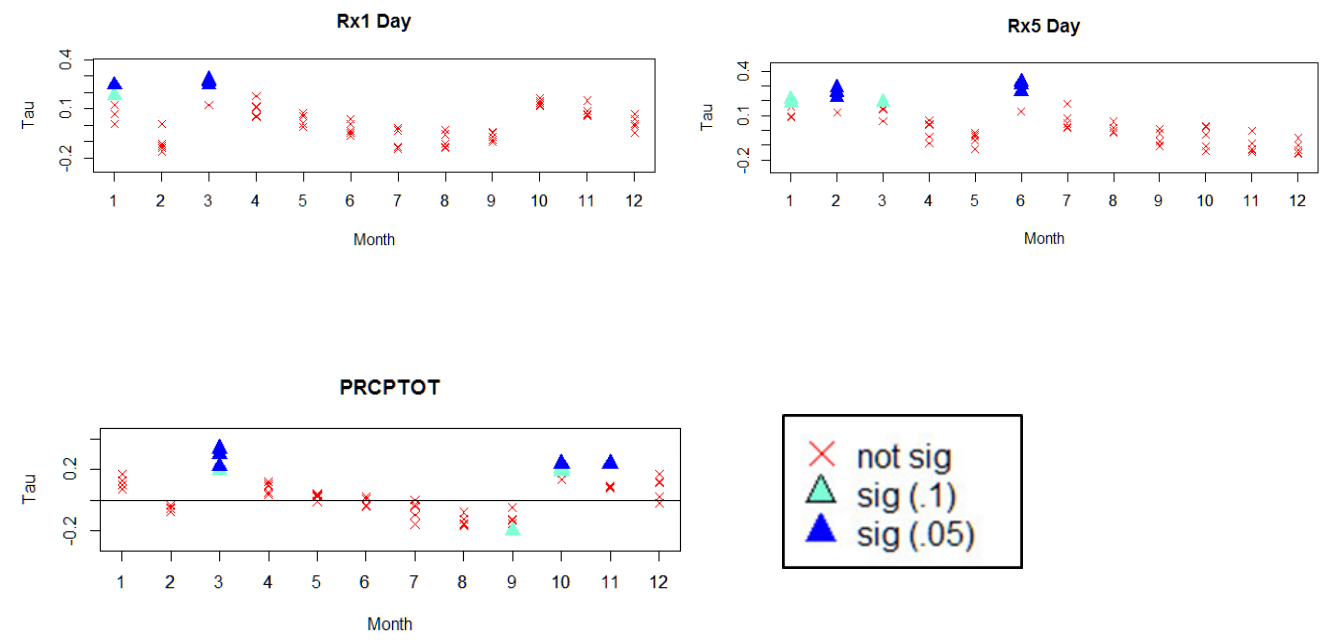

Figure 7. Monthly index trends for Portland, OR observations for 1977-2016 including Rx1day, Rx5day, PRCPTOT. Indices represent single day rain (Rx1day), 5 day rain (Rx5day), total rainfall (PRCPTOT).

Temperature variables also show departure from annual results (Figure 8). The index TNn is significantly increasing in summer months at 5\%, while TXx is significant in none. A stepped pattern in the steepness of temperature increase is apparent in the temperature minimums where June, July, August, September, and October are all significant.
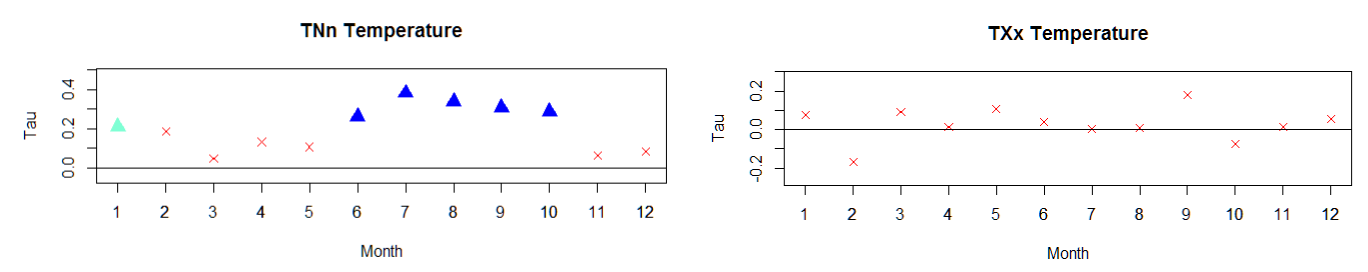

Figure 8. Monthly index trends for Portland, OR observations for 1977-2016 including TNn, TXx. Indices represent temperature minimum (TNn) and temperature maximum (TXx). Legend same as Figure 7.

Comparison of monthly SDII at the daily and hourly scale indicate that the hourly scale analysis detected many more trends than annual scale analysis. Monthly SDII at the daily scale is significant in January, March and November (Figure 9). Monthly SDII at the hourly scale is significant at 5\% in January, March, April, October and November 
(Figure 10).

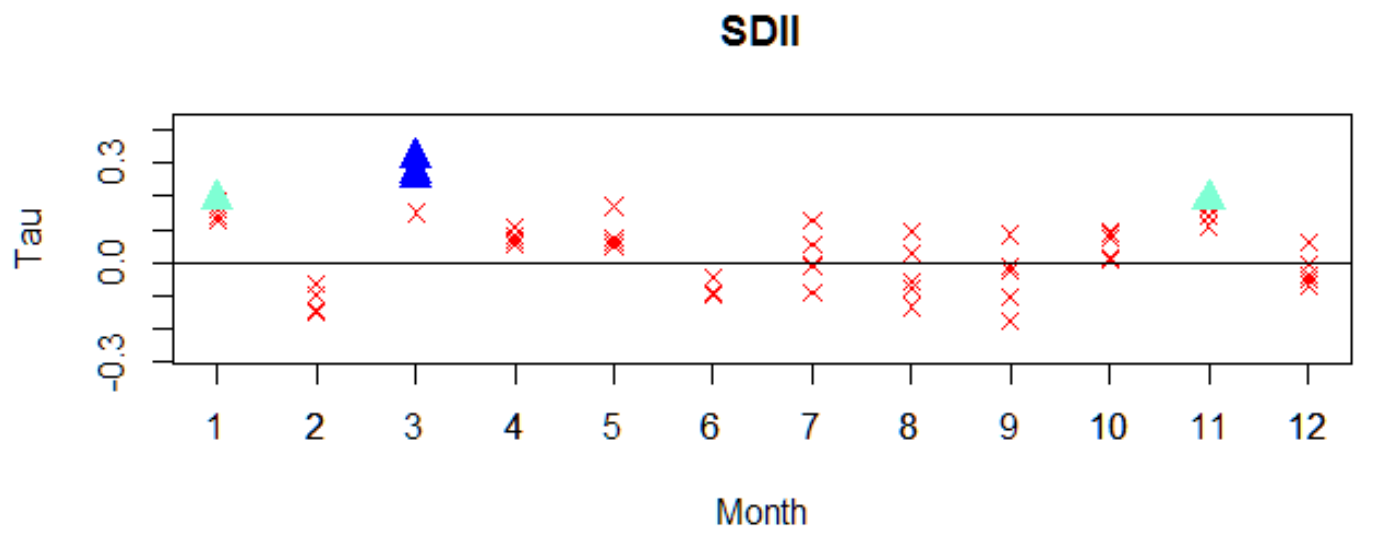

Figure 9. Monthly index trends for Portland, OR observations for 1977-2016 including daily scale rain intensity (SDII). Legend same as Figure 7.

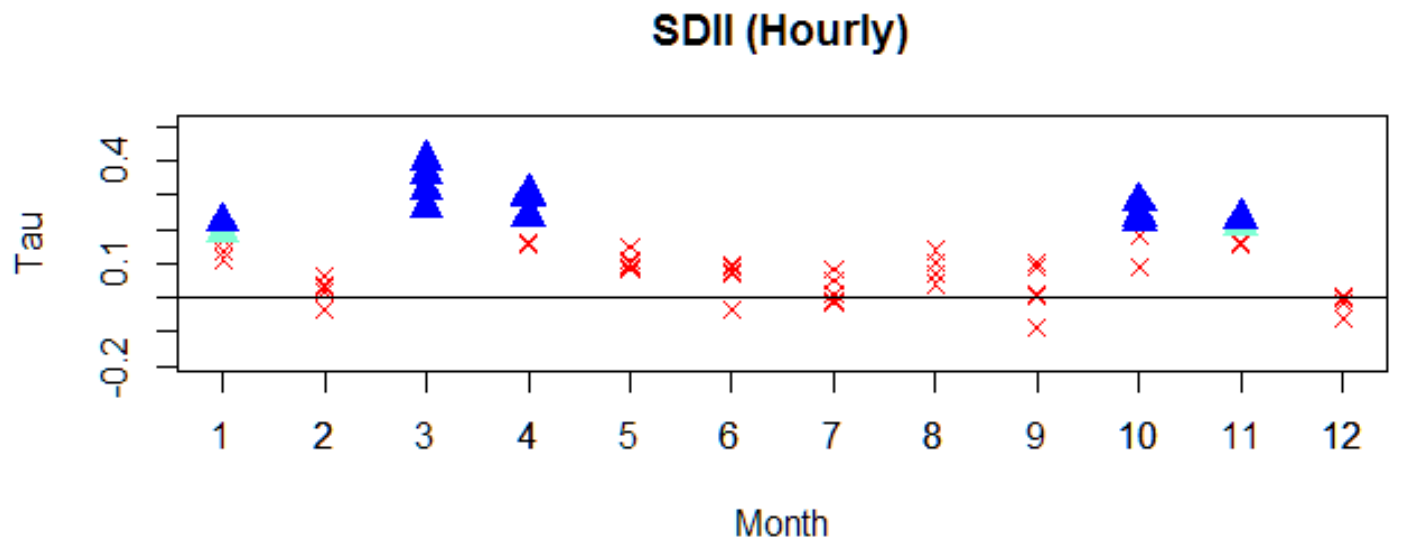

Figure 10. Monthly index trends for Portland, OR observations for 1977-2016 including hourly scale rain intensity (SDII-Hourly). Legend same as Figure 7.

Results from autocorrelation testing showed that autocorrelation decreased when period of study was changed from annual to monthly. At the annual scale, autocorrelation in annual PCRPTOT and SDII values was detected. Since only PRCPTOT was significant, bootstrapping was used to check the range of potential tau values for stations 
autocorrelated data. Results indicated that tau values could range between positive and negative, and that the increasing PRCPTOT tau values observed are be subject to the possibility of false positive detection (Kulkarni and von Storch, 1995). Autocorrelation tests at the monthly scale showed that the strength of autocorrelation is minimal in PRCPTOT and removed entirely for SDII.

Exploration of $700 \mathrm{mb}$ atmosphere temperature resulted in a significant trend in minimum temperatures is March at 5\%, while monthly maximum temperature shows a significant trend in July at 10\% (Figure 11).
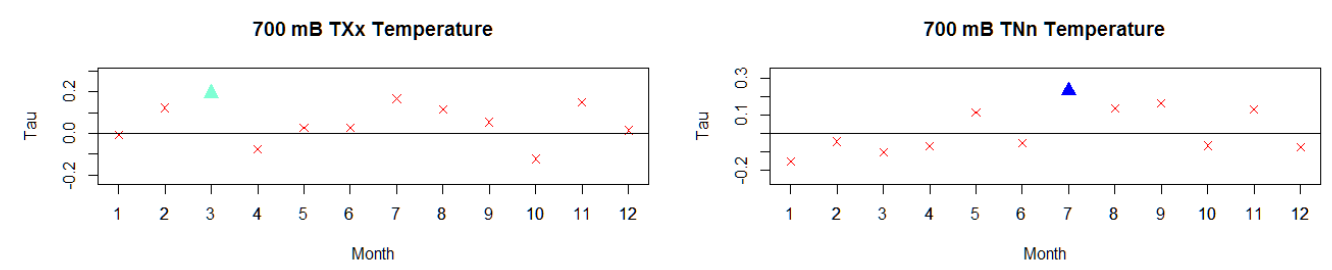

Figure 11. Monthly index trends for atmospheric soundings at 700mb for 1977-2016 including TXx, TNn. Indices represent maximum temperature (TXX) and minimum temperature (TNn). Legend same as Figure 7.

\subsection{Results for Question 3: ETCCDI Indices and Peak Streamflow}

All ETCCDI Indices were shown to be statistically significantly correlated with maximum discharge events at most stations (Figure 12). Of the standard ETCCDI indices, Rx5day performs best with a significant correlation of .49 at Station 6. SDII hourly scale outperforms SDII daily scale at all stations. Station 58 is notable for its lack of significant correlation. It is notable that Station 58, located on the far west side of Portland, OR, is the furthest from the Sycamore stream gage station. 

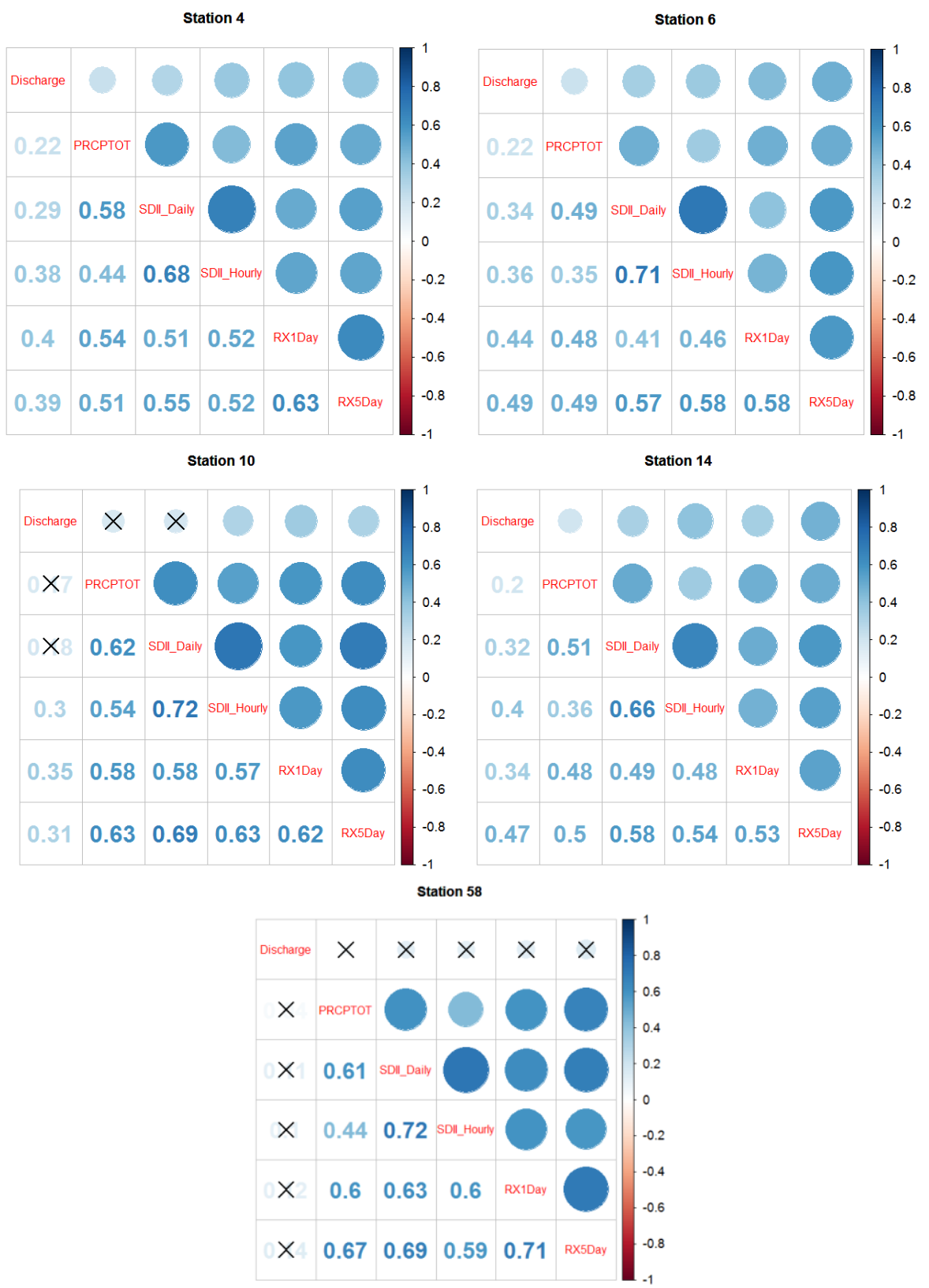

Figure 12. Kendall rank coefficients for correlation of monthly indices and peak flow at Johnson Creek during 40 maximum flow events occurring from 1977-2016. Indices include total rainfall (PRCPTOT), daily intensity (SDII), hourly intensity (SDII-hourly), single day rainfall (Rx1day), 5 day rainfall (Rx5day). 
The purpose of this study was to use widely adopted precipitation indices to characterize trends in precipitation in Portland, OR. Comparing trends in indices from 1977-2005 rain station records with three downscaled climate models resulted in consistently non-significant mixed direction trends. Climate model projections under maximum emissions scenario RCP 8.5 for 2006-2100 resulted in significant increasing trends in precipitation intensity from two of three models. Analysis of a different suite of precipitation indices for 1977-2016 at annual and monthly periods indicated that trends are largely apparent only at the sub-annual scale of analysis. Increased intensity and wet spell volume are identified in fall, winter and spring, consistent with long-term climate projections from models. Correlation between precipitation indices and streamflow indicated that measurements of consecutive wet day rainfall is the best predictor of peak flow. Increases in heavy and extreme rainfall indices indicate the potential for increased flood risk in local Portland streams.

Comparison of observed and modelled rainfall in Portland, OR for 1977-2005 show both observed and projected rainfall lack significant trends. Non-significant increasing and decreasing trends are found in annual indices representing consecutive dry days (CDD), wet days (CWD), rainfall occurring as heavy precipitation (R95p) and daily intensity (SDII). The observations from the five Portland, OR stations are consistent with historic projections from models CanESM2, CESM1-CAM5, CNRM-CM5 in the sense that overall few trends in the select indices are observed. 
Global analysis of ensemble climate projections characterizes future rainfall as more intense, coming in shorter duration heavy events amidst more enduring dry periods (Giorgi et al., 2014). This research considers the RCP 8.5 maximum emissions scenario where the influence of increased greenhouse gases on climate is greatest. Results from climate model precipitation projections for 2006-2100 indicate that the conditions of increased intensity are a possibility for the Portland, OR area but enduring dry periods less certain. An increase in the volume of annual rainfall coming from heavy events (R95p) is consistent across two climate models including CanESM2 and CNRM-CM5; the increasing trend in R95p is almost significant in CESM1-CAM5 (tau=.11,pvalue=.13). Significant increase in daily rainfall intensity (SDII) is also observed in the CanESM2 and CNRM-CM5 model projections. However, the CESM1-CAM5 model does not show increased SDII observed in the other models. The disagreement between models points to uncertainty in changes that may be experienced by the Portland, OR area.

Some models indicate that central Pacific sea temperature rise and eastward shift of North Pacific storm track precipitation may contribute longer wet spells to the US west coast (Karin and Zwiers, 2000). A strong signal of increased annual total precipitation was apparent in the Portland rain gage network from 1977-2016. This is consistent with increased regional precipitation observed over $21^{\text {st }}$ century (Mote and Salathé, 2010). The cause of this increase is not apparent. Changes to the North Pacific storm track that bring more rain are expected for later in the century (Yin, 2005). 
Sub-annual analysis of monthly precipitation characteristics of the Portland 19772016 record reveals greater change to the hydrologic cycle including intense precipitation, heavier events and greater monthly rainfall. The rate of rainfall during storm events is expected to increase considerably with climate change, proportional to increases in water vapor in a warmer atmosphere (Trenberth et al., 2003). However, ensemble climate models projects little change to Pacific Northwest annual mean precipitation during the $21^{\text {st }}$ century (Mote and Salathé, 2010). In order for mean precipitation to go unchanged while heavy rainfall increases, increases to heavy rainfall would be compensated for by decreased moderate and light rainfall (Karl and Knight, 1998). In this study, increased precipitation was coupled with increased intensity without compensatory decreases as expected. Results from sub-annual analysis do not match projections that mean precipitation will remain unchanged while intensity increases.

Seasonal trends of rainfall intensity and increased volume are partially consistent with expectations from global climate model projections that expect increased intensity and volume in winter months. Trends in monthly precipitation indices are concentrated in fall, winter and spring months. March has the highest concentration of observed precipitation change, including increase in intensity, volume, and single day rainfall (SDII, PRCPTOT, Rx1day). The physical mechanisms generating this change are unclear. Increase to spring storm intensity in British Columbia is observed, but the area also experienced increased intensity in summer that are not apparent here (Jakob et al., 2003; Burn and Taleghani, 2013). Neither surface temperature minimums nor maximums significantly changed in March. The increased heavy rainfall in March may be related to 
the significant increase in temperature observed at $700 \mathrm{mb}$ (Figure 11). The majority of precipitable moisture occurs at or below $500 \mathrm{mb}$, and upper atmospheric temperatures act as a control on this moisture content (Ross and Elliot, 1996). Increased temperatures at $700 \mathrm{mb}$ may equate to decreased limitation on upper atmosphere moisture content, resulting in additional precipitable water transported at high altitudes that is available for precipitation. Temperature patterns at the surface and upper atmosphere may also contribute to the lack of increasing trends in summer months. All summer months showed significant increase in temperature minimums. These increased temperatures may result in reduced condensation. However, decreases in precipitation that may be expected to accompany surface and atmospheric warming are not yet apparent. Overall, seasonal analysis of Portland rainfall records indicate the area is experiencing hydrologic change, including more rain and more intense rainfall events in all seasons except summer.

The reliance on daily rainfall totals in the ETCCDI methodology is shown to limit trend detection compared with hourly rainfall totals. Daily scale records resulted in fewer significant trends than hourly scale records. At the 5\% significance level daily records were significant in March while hourly records were significant in more months including January, March, April, October, and November. This is consistent with expectations that daily scale records suppress intensity trend detection compared with hourly scale records (Cooley and Chang, 2017). Compared to temperature, precipitation occurs at smaller spatial and temporal scales that are more difficult to measure (Boer et al., 2000). For this reason gage spatial density and temporal resolution that is appropriate for temperature may not be appropriate for precipitation. The high spatial and temporal 
resolution of the data available in Portland's HYDRA network thus is an asset for the local area, although these trends cannot necessarily be extrapolated to the greater region. Analysis of Portland's gage network from 1977-2016 indicates that when precipitation indices are adapted to a higher temporal resolution and tested for monthly periods, a greater extent of hydrologic change can be observed.

Although results from this study suggest that Portland's hydrologic cycle has intensified from 1977-2016, the physical mechanisms causing this change are ultimately uncertain. Climate change may be responsible for changes through increased evaporation and water vapor transport but examination of the dynamics of transport and condensation occurring from 1977-2016 are outside the scope of work. Attribution of events to climate change remains an active area of research and relevant methods are not adopted here (van der Wiel et al., 2017). This paper uses the basic hallmarks of an intensified hydrologic cycle as a hypothesis for the conditions of climate change in Portland, OR, but does not attempt to show greenhouse gas forcing is required for the intensification observed. The role of natural climate variability in these changes is unknown. Natural variability is thought to be responsible for an increase in mean precipitation observed in the Pacific Northwest over the $20^{\text {th }}$ century and may play a role in rainfall intensification (Mote, 2003a). Further, among the three climate models explored, only two support significant intensification of the hydrologic cycle for 2006-2100. Expanding this work to include more models and grid points for the Portland, OR area could more conclusively explore whether the area will experience an intensified hydrologic cycle. 
Finally, this study showed that the ETCCDI precipitation indices measuring wet spell volume (Rx5day) correlate best with peak flow events in local streamflow. This is consistent with similar studies where rainfall metrics that capture multi-day rainfall totals outperform metrics that capture single day volume or intensity (Pitlick, 1994; Pielke and Downton, 2000). The ETCCDI indices may therefore act as a meaningful proxy of future flood risk. The standardized methodologies of the ETCCDI indices have an advantage over other precipitation metrics that may be custom developed for individual studies such as those used in Pielke and Downton (2000). The maximum correlation between peak flow and an ETCCDI index is .49 , showing that other variables such as basin area and steepness contribute to the relationship between rainfall and peak flow. For individual storms, storm intensity can overcome the importance of total volume, but these instances are not the majority (Bracken et al., 2008).

The importance of wet spell volume in predicting peak flow means that future trends in this characteristic of precipitation may mean increased flood risk. Results from this study indicate wet spell volumes (Rx5day) are increasing in January, February and June. As peak flow events are already concentrated in winter months, increased precipitation input in January and February may foretell increased exposure to flood risk. Trends in future consecutive wet days (CWD) are not consistent between selected downscaled global climate models of rainfall for 2006-2100, although the CanESM2 model showed increased wet spell length (CWD). Another Canadian climate model, the Canadian Global Coupled Model (CGCM1) indicates there is a latitudinal gradient of change in this variable along western North America where southern areas experience a 
decrease in wet spell length and northern areas indicate an increase in wet spell length (Kharin and Zwiers, 2000). The fact that our study area lies in the middle of the North American continent suggests there may be considerable uncertainty in which path this variable may take. If current trends in rainfall volume and annual wet spell length continue to increase as observed in the Portland rainfall network from 1977-2016, it may indicate increased flood risk for the area. 


\section{Chapter 6. Conclusions}

This study used the ETCCDI precipitation indices and Mann-Kendall trend detection to characterize trends in precipitation in Portland, OR. Observed records from rain gages in Portland are compared with historic (1977-2005) and future (2006-2100) projections from three LOCA downscaled global climate models for the Portland area. Annual trends indicate that, although two of three models portray an intensifying hydrologic cycle from 2006-2100, these conditions were not detected in the observational record. However, when the period of study is changed from annual to monthly, many of the hallmarks of an intensified hydrologic cycle are detected in the observational record in spring, winter and fall months. Trend detection of increasing precipitation intensity became even more robust after data resolution was changed from daily to hourly. The increasing trends detected in ETCCDI precipitation indices have important consequences for Portland flood risk because the indices are shown to correlate well with peak flow in a flood-prone local stream, Johnson's Creek. The observed trends of prolonged wet spells with greater volume are likely indicative of increased flood risk for people in the Johnson's creek flood zone. 
Works Cited

Abatzoglou, JT, Rupp D, Mote PW. 2014. Seasonal climate variability and change in the Pacific Northwest of the United States. Journal of Climate 27 (5): 2125 2142.

Ahilan S, Guan M, Sleigh A, Wright N, Chang H. 2016. The Influence of Floodplain Restoration on Flow and Sediment Dynamics in an Urban River. Journal of Flood Risk Management.

Berg, P, Haerter JO, Thejll P, Piani C, Hagemann S, Christensen JH. 2009. Seasonal characteristics of the relationship between daily precipitation intensity and surface temperature. Journal of Geophysical Research: Atmospheres 114 (D18). http://onlinelibrary.wiley.com/doi/10.1029/2009JD012008/full.

Boer, GJ, Flato G, Reader MC, Ramsden D. 2000. A transient climate change simulation with greenhouse gas and aerosol forcing: experimental design and comparison with the instrumental record for the twentieth century. Climate Dynamics 16 (6): 405425.

Bracken LJ, Cox NJ, Shannon J. 2008. The Relationship between Rainfall Inputs and Flood Generation in South-east Spain. Hydrological Processes 22 (5): 683-96.

Brommer, DM, Cerveny RS, Balling Jr. RC 2013. An analysis of intra-event precipitation variability for the United States (1980-2010). Physical Geography 34 (6): 456-470.

Burn, DH, Taleghani A. 2013. Estimates of changes in design rainfall values for Canada. Hydrological Processes 27 (11): 1590-1599. 1.7.

Canty A, Ripley B. 2012. boot: Bootstrap R (S-Plus) functions. R package version

Chang, H. 2007. Comparative streamflow characteristics in urbanizing basins in the Portland Metropolitan Area, Oregon, USA. Hydrological Processes 21 (2): 211-222.

Chang H, Lafrenz M, Jung I, Figliozzi M, Platman D, Pederson C. 2010. Potential Impacts of Climate Change on Flood-Induced Travel Disruptions: A Case Study of Portland, Oregon, USA. Annals of the Association of American Geographers 100 (4): 938-952.

Chang, H, Jung I, Steele M, Gannett M. 2012. Spatial patterns of March and September streamflow trends in Pacific Northwest streams, 1958-2008. Geographical Analysis 44 (3): 177-201.

Chou C, Chen C, Tan P, Chen KT. 2012. Mechanisms for global warming impacts on precipitation frequency and intensity. Journal of Climate 25 (9): 3291-3306.

Cooley A, Chang H. 2017. Precipitation intensity trend detection using hourly and daily observations in Portland, Oregon. Climate 5 (1): 10. 
Dai, A. 2011. Drought under global warming: a review. Wiley Interdisciplinary Reviews: Climate Change, 2 (1),:45-65.

Dart, J. O.; Johnson, D. M. Oregon, Wet, High and Dry.; Hapi Press: Portland, OR, 1981.

Davison AC, Hinkley DV. 1997. Bootstrap methods and their application Vol. 1. Cambridge University Press.

de los Milagros SM, Brunet M, Sigró, J, Aguilar E, Groening, JA, Bentancur OJ., Rojas $\mathrm{C}, \ldots .2013$. Warming and wetting signals emerging from analysis of changes in climate extreme indices over South America. Global and Planetary Change 100: 295307.

Dettinger M. 2011. Climate change, atmospheric rivers, and floods in California a multimodel analysis of storm frequency and magnitude changes. Journal of the American Water Resources Association 47 (3): 514-23.

Diaz FL, Conde C, Sánchez O. 2012. Analysis of indices of extreme temperature events at Apizaco, Tlaxcala, Mexico: 1952-2003. Atmósfera, 26 (3).

Dore MH. 2005. Climate change and changes in global precipitation patterns: what do we know? Environment International 31 (8): 1167-81.

Dumitrescu A, Bojariu R, Birsan MV, Marin L, Manea, A. 2015. Recent climatic changes in Romania from observational data (1961-2013). Theoretical and Applied Climatology, 122 (1-2): 111-119.

Filahi S, Tanarhte M, Mouhir L, El Morhit M, Tramblay Y. 2016. Trends in indices of daily temperature and precipitations extremes in Morocco. Theoretical and Applied Climatology, 124 (3-4): 959-972.

Frich P, Alexander L, Della-Marta B, Gleason MH, Tank AK, Peterson TC. 2002. Observed coherent changes in climatic extremes during 2nd half of the 20th century. ResearchGate 19 (3).

Giorgi F, Lm ES, Coppola E, Diffenbaugh NS, Gao XJ, Mariotti L, Shi Y. 2011. Higher hydroclimatic intensity with global warming. Journal of Climate 24 (20): 53095324.

Giorgi F, Coppola E, Raffaele F. 2014. A consistent picture of the hydroclimatic response to global warming from multiple indices: models and observations. Journal of Geophysical Research: Atmospheres, 119 (20).

Groisman, Ya P, Karl TR, Easterling DR, Knight RW, Jamason PF, Hennessy KJ, Suppiah R, Page C, Wibig J, Fortuniak K, ... 1999. Changes in the probability of heavy precipitation: important indicators of climatic change. Climatic Change 42 (1): 243-283.

Groisman, Ya P, Knight RW, Easterling DR, Karl TR, Hegerl GC, Razuvaev VN. 2005. Trends in Intense Precipitation in the Climate Record. Journal of Climate 18 (9): 1326-1350. 
Held IM, Soden BJ. 2006. Robust responses of the hydrological cycle to global warming. Journal of Climate 19 (21): 5686-5699.

Hense, A, Krahe P, Flohn H. 1988. Recent fluctuations of tropospheric temperature and water vapour content in the tropics. Meteorology and Atmospheric Physics 38 (4): 215-227.

Hershfield, DM. 1963. Rainfall frequency atlas of the United States: for durations from 30 minutes to 24 hours and return periods from 1 to 100 years. Department of Commerce, Weather Bureau.

Horn, LH, Bryson RA. 1960. Harmonic analysis of the annual march of precipitation over the United States. Annals of the Association of American Geographers 50 (2): 157-171.

Houghton J, Jenkins GJ, Ephraums JJ. 1990. Scientific assessment of climate change-report of working group I, Vol. I of IPCC First Assessment Report. Cambridge, UK: Cambridge University Press.

Huntington, TG. 2006. Evidence for intensification of the global water cycle: review and synthesis. Journal of Hydrology 319 (1): 83-95.

Intergovernmental Panel on Climate Change (IPCC). 2013. Contribution of working group I to the Fifth Assessment Report of the Intergovernmental Panel on Climate Change. Climate Change 2013: The Physical Science Basis. Cambridge, U.K.: Cambridge Univ. Press.

Jakob M, McKendry I, Lee R. 2003. Long-term changes in rainfall intensities in Vancouver, British Columbia. Canadian Water Resources Journal / Revue Canadienne Des Ressources Hydriques 28 (4): 587-604. doi:10.4296/cwrj2804587.

Jiang P, Zhongbo Y, Mahesh RG, Yuan F, Acharya K. 2016. Changes of storm properties in the united states: observations and multimodel ensemble projections. Global and Planetary Change 142 (July): 41-52.

Karl TR, Knight RW. 1998. Secular trends of precipitation amount, frequency, and intensity in the United States. Bulletin of the American Meteorological Society 79 (2): 231-241.

Karl TR, Nicholls N, Ghazi A, 1999. CLIVAR/GCOS/WMO workshop on indices and indicators for climate extremes: Workshop summary. Climatic Change, $\mathbf{4 2}$ : 3-7.

Kharin VV, Zwiers FW. 2000.Changes in the extremes in an ensemble of transient climate simulations with a coupled atmosphere-ocean GCM. Journal of Climate 13 (21): 3760-3788.

King, AD, Klingaman NP, Alexander LV, Donat MG, Jourdain NC, Maher P. 2014. Extreme rainfall variability in Australia: Patterns, drivers, and predictability. Journal of Climate, 27 (15): 6035-6050. 
Krishnamurthy CK, Lall U, Kwon H. 2009. Changing frequency and intensity of rainfall extremes over India from 1951 to 2003. Journal of Climate 22 (18): 4737-4746.

Kruger AC, Sekele SS. 2013. Trends in extreme temperature indices in South Africa: 1962-2009. International Journal of Climatology 33(3): 661-676.

Kulkarni A, von Storch H. 1995. Monte Carlo experiments on the effect of serial correlation on the Mann-Kendall test of trend. Meteorologische Zeitschrift 4 (2): 82-85.

Luce CH, Holden ZH. 2009. Declining annual streamflow distributions in the Pacific Northwest United States, 1948-2006. Geophysical Research Letters 36 (16): L16401. doi:10.1029/2009GL039407.

Lundquist JD, Cayan DR. 2002. Seasonal and spatial patterns in diurnal cycles in streamflow in the western United States. Journal of Hydrometeorology 3 (5): 591-603.

Mann HB. Nonparametric tests against trend. 1945. Econometrica: Journal of the Econometric Society: 245-259.

Martin-Vide J. 2004. Spatial distribution of a daily precipitation concentration index in peninsular Spain. International Journal of Climatology 24 (8): 959-71. doi:10.1002/joc. 1030 .

McLeod, AI. 2005. Kendall rank correlation and Mann-Kendall trend test. $\mathrm{R}$ Package Kendall.

McMichael AJ, Woodruff RE, Hales S. 2006. Climate change and human health: present and future risks. The Lancet, 367 (9513): 859-869.

Moberg A, Jones PD, Lister D, Walther A, Brunet M, Jacobeit J, Alexander LV.... 2006. Indices for daily temperature and precipitation extremes in Europe analyzed for the period 1901-2000. Journal of Geophysical Research: Atmospheres 111 (D22): D22106.

Mote, PW. 2003a. Trends in temperature and precipitation in the Pacific Northwest during the twentieth century. Northwest Science, 77: 271-282.

. 2003b. Trends in snow water equivalent in the Pacific Northwest and their climatic causes. Geophysical Research Letters 30 (12): 1601. doi:10.1029/2003GL017258.

Mote, PW, Salathé Jr. EP. 2010. Future climate in the Pacific Northwest. Climatic Change 102 (1-2): 29-50.

Munoz EA, Di Paola D, Lanfri M. 2015. Advances on rain rate retrieval from satellite platforms using artificial neural networks. IEEE Latin America Transactions $\mathbf{1 3}$ (10): 3179-3186.

Oliver JE. 1980. Monthly precipitation distribution: a comparative index. The Professional Geographer 32 (3): 300-309. doi:10.1111/j.0033-0124.1980.00300.x. 
Osborn TJ, Hulme M, Jones PD, Basnett TA. 2000. Observed trends in the daily intensity of United Kingdom precipitation. International Journal of Climatology 20 (4): 347-364.

Panda DK, Panigrahi P, Mohanty S, Mohanty RK, Sethi RR. 2016. The 20th century transitions in basic and extreme monsoon rainfall indices in India: Comparison of the ETCCDI indices. Atmospheric Research 181: 220-235.

Parker LE, Abatzoglou JT. 2016. Spatial coherence of extreme precipitation events in the northwestern United States. International Journal of Climatology 36 (6): 2451-60.

Peel MC, Finlayson BL, McMahon TA. 2007. Updated world map of the KöppenGeiger climate classification. Hydrology and Earth System Sciences Discussions 4 (2): 439-473.

Peterson TC, Folland C, Gruza G, Hogg W, Mokssit A, Plummer N. 2001. Report on the activities of the working group on climate change detection and related rapporteurs 1998-2001. WMO: Geneva, Switzerland.

Peterson TC, Manton MJ. 2008. Monitoring changes in climate extremes: a tale of international collaboration. Bulletin of the American Meteorological Society 89 (9): 12661271.

Pielke Jr RA, Downton MW. 2000. Precipitation and Damaging Floods: Trends in the United States, 1932-97. Journal of Climate 13 (20): 3625-3637.

Pierce DW, Cayan DR, Thrasher BL. 2014. Statistical downscaling using localized constructed analogs (LOCA). Journal of Hydrometeorology 15 (6): 2558-2585.

Praskievicz S, Chang H. 2009. Winter Precipitation Intensity and ENSO/PDO Variability in the Willamette Valley of Oregon. International Journal of Climatology 29 (13): 2033-2039.

Prein AF, Rasmussen RM, Ikeda K, Liu C, Clark MP, Holland GJ. 2016. The future intensification of hourly precipitation extremes. Nature Climate Change 7 (1): 4852. doi:10.1038/nclimate3168.

R Core Team. 2014. R: A language and environment for statistical computing. $\mathrm{R}$ Foundation for Statistical Computing, Vienna, Austria.

Rahimzadeh F, Asgari A, Fattahi E. 2009. Variability of extreme temperature and precipitation in Iran during recent decades. International Journal of Climatology 29(3): 329-343.

Redmond KT, Koch RW. 1991. Surface climate and streamflow variability in the western United States and their relationship to large-scale circulation indices. Water Resources Research 27 (9): 2381-2399.

Riahi K, Rao S, Krey V, Cho C, Chirkov V, Fischer G, Kindermann G, Nakicenovic N, Rafaj P. 2011. RCP 8.5-A scenario of comparatively high greenhouse gas emissions. Climatic Change 109(1-2): 33. 
Ross RJ, Elliott WP. 1996. Tropospheric water vapor climatology and trends over North America: 1973-93. Journal of Climate 9 (12): 3561-3574.

Rubel R, Kottek M. 2010. Observed and projected climate shifts 1901-2100 depicted by world maps of the Köppen-Geiger climate classification. Meteorologische Zeitschrift, 19 (2): 135-141.

Rupp DE, Abatzoglou JT, Hegewisch KC, Mote PW. 2013. Evaluation of CMIP5 20th century climate simulations for the Pacific Northwest USA. Journal of Geophysical Research: Atmospheres, 118 (19).

Salathé EP. 2003. Comparison of various precipitation downscaling methods for the simulation of streamflow in a rainshadow river basin. International Journal of Climatology. 23: 887-901.

- 2006. Influences of a shift in north Pacific storm tracks on western North American precipitation under global warming. Geophysical Research Letters 33 (19).

Salathé P, Hamlet AF, Stumbaugh M, Lee SY, Steed R. 2014. Estimates of 21st Century flood risk in the Pacific Northwest based on regional scale climate model simulations. Journal of Hydrometeorology. 15: 1881-1899.

Sanò P, Panegrossi G, Casella D, Di Paola F, Milani L, Mugnai A, Petracca M, Dietrich S. 2015. The passive microwave neural network precipitation retrieval (PNPR) algorithm for AMSU/MHS observations: description and application to European case studies. Atmospheric Measurement Techniques 8 (2): 837-857.

Seneviratne SI, Lüthi D, Litschi M, Schär C. 2006. Land-atmosphere coupling and climate change in Europe. Nature 443 (7108): 205-209. doi:10.1038/nature05095.

Soulis ED, Sarhadi A, Tinel M, Suthar M. 2016. Extreme precipitation time trends in Ontario, 1960-2010. Hydrological Processes 30 (22): 4090-4100. doi:10.1002/hyp. 10969.

Tangang F, Juneng, L., Aldrian E. 2017. Observed changes in extreme temperature and precipitation over Indonesia. International Journal of Climatology 37 (4): 1979-1997.

Taylor KW, Stouffer RJ, Meehl GA. 2012. An overview of CMIP5 and the experiment design. Bulletin of the American Meteorological Society 93 (4): 485-498.

Thibeault JM, Seth A. 2014. Changing climate extremes in the Northeast United States: observations and projections from CMIP5. Climatic change, 127 (2): 273-287.

Tohver IM, Hamlet AF, Lee SY. 2014. Impacts of 21st-Century climate change on hydrologic extremes in the Pacific Northwest region of North America. Journal of the American Water Resources Association 50 (6): 1461-1476.

Trenberth KE. 1998. Atmospheric moisture residence times and cycling: implications for rainfall rates and climate change. Climatic Change 39 (4): 667-694. 
. 2011. Changes in precipitation with climate change. Climate Research 47 (1-2): 123-138.

Trenberth KE, Dai A, Rasmussen RM, Parsons DB. 2003. The changing character of precipitation. Bulletin of the American Meteorological Society 84 (9): 1205-1217.

Turco M, Llasat MC. 2011. Trends in indices of daily precipitation extremes in Catalonia (NE Spain), 1951-2003. Natural Hazards and Earth System Sciences 11 (12): 3213-3226.

van der Wiel K, Kapnick SB, van Oldenborgh GJ, Whan K, Philip S, Vecchi GA, Singh RK, Arrighi J, Cullen H. 2017. Rapid attribution of the August 2016 floodinducing extreme precipitation in south Louisiana to climate change. Hydrology and Earth System Sciences 21 (2): 897.

Vicente-Serrano SM, Chura O, López-Moreno JI, Azorin-Molina C, SanchezLorenzo A, Aguilar E, Nieto JJ.... 2015. Spatio-temporal variability of droughts in Bolivia: 1955-2012. International Journal of Climatology 35(10): 3024-3040.

Wang S, Huang GH, Lin QG, Li Z, Zhang H, Fan YR. 2014. Comparison of interpolation methods for estimating spatial distribution of precipitation in Ontario, Canada. International Journal of Climatology, 34 (14): 3745-3751.

Wentz FJ, Ricciardulli L, Hilburn K, Mears C. 2007. How much more rain will global warming bring? Science 317 (5835): 233-235. doi:10.1126/science.1140746.

Xu C, Widén E, Halldin S. 2005. Modelling hydrological consequences of climate change - progress and challenges. Advances in Atmospheric Sciences 22 (6): 789-797. doi:10.1007/BF02918679.

Xu W, Zou Y, Zhang G, Linderman M. 2015. A comparison among spatial interpolation techniques for daily rainfall data in Sichuan Province, China. International Journal of Climatology 35 (10): 2898-2907.

Yin JH. 2005. A consistent poleward shift of the storm tracks in simulations of 21st century climate. Geophysical Research Letters, 32 (18).

Zandonadi L, Acquaotta F, Fratianni S, Zavattini JA. 2016. Changes in precipitation extremes in Brazil (Paraná River basin). Theoretical and Applied Climatology 123 (3-4): 741-756.

Zhang X, Yang F. 2004. RClimDex (1.0) user manual. Climate Research Branch Environment Canada 22.

Zhang X, Zwiers FW, Hegerl GC, Lambert FH, Gillett NP, Solomon S, Stott PA, Nozawa T. 2007. Detection of human influence on twentieth-century precipitation trends. Nature 448 (7152): 461-65. doi:10.1038/nature06025.

Zhang X, Alexander L, Hegerl GC, Jones P, Tank AK, Peterson TC, Trewin B, Zwiers FW. 2011. Indices for monitoring changes in extremes based on daily temperature and precipitation data. Wiley Interdisciplinary Reviews: Climate Change 2 (6): 851-70. doi:10.1002/wcc.147. 


\section{Appendix. ETCCDI Indicator Definitions}

\begin{tabular}{|c|c|c|c|}
\hline ID* & Indicator name & Definitions & Units \\
\hline FD0 & Frost days & Annual count when $\mathrm{TN}($ daily minimum $)<0^{\circ} \mathrm{C}$ & Days \\
\hline SU25 & Summer days & Annual count when $\mathrm{TX}($ daily maximum $)>25^{\circ} \mathrm{C}$ & Days \\
\hline ID0 & Ice days & Annual count when $\mathrm{TX}$ (daily maximum $)<0^{\circ} \mathrm{C}$ & Days \\
\hline TR20 & Tropical nights & Annual count when $\mathrm{TN}($ daily minimum $)>20^{\circ} \mathrm{C}$ & Days \\
\hline GSL & $\begin{array}{l}\text { Growing season } \\
\text { Length }\end{array}$ & $\begin{array}{l}\text { Annual (1st Jan to } 31^{\text {st }} \text { Dec in NH, } 1^{\text {st }} \text { July to } 30^{\text {th }} \\
\text { June in } \mathrm{SH} \text { ) count between first span of at least } 6 \text { days } \\
\text { with TG }>5^{\circ} \mathrm{C} \text { and first span after July } 1 \text { (January } 1 \text { in } \\
\text { SH) of } 6 \text { days with } \mathrm{TG}<5^{\circ} \mathrm{C}\end{array}$ & Days \\
\hline TXx & Max Tmax & Monthly maximum value of daily maximum temp & ${ }^{\circ} \mathrm{C}$ \\
\hline $\mathrm{TNx}$ & Max Tmin & Monthly maximum value of daily minimum temp & ${ }^{\circ} \mathrm{C}$ \\
\hline TXn & Min Tmax & Monthly minimum value of daily maximum temp & ${ }^{\circ} \mathrm{C}$ \\
\hline $\mathrm{TNn}$ & Min Tmin & Monthly minimum value of daily minimum temp & ${ }^{\circ} \mathrm{C}$ \\
\hline TN10p & Cool nights & Percentage of days when $\mathrm{TN}<10$ th percentile & Days \\
\hline TX10p & Cool days & Percentage of days when $\mathrm{TX}<10$ th percentile & Days \\
\hline TN90p & Warm nights & Percentage of days when $\mathrm{TN}>90$ th percentile & Days \\
\hline TX90p & Warm days & Percentage of days when $T X>90$ th percentile & Days \\
\hline WSDI & $\begin{array}{l}\text { Warm spell duration } \\
\text { indicator }\end{array}$ & $\begin{array}{l}\text { Annual count of days with at least } 6 \text { consecutive days } \\
\text { when } T X>90 \text { th percentile }\end{array}$ & Days \\
\hline CSDI & $\begin{array}{l}\text { Cold spell duration } \\
\text { indicator }\end{array}$ & $\begin{array}{l}\text { Annual count of days with at least } 6 \text { consecutive days } \\
\text { when } T N<10 \text { th percentile }\end{array}$ & Days \\
\hline DTR & $\begin{array}{l}\text { Diurnal temperature } \\
\text { range }\end{array}$ & Monthly mean difference between TX and TN & ${ }^{\circ} \mathrm{C}$ \\
\hline Rx1day & $\begin{array}{l}\text { Max 1-day } \\
\text { precipitation amount }\end{array}$ & Monthly maximum 1-day precipitation & $\mathrm{Mm}$ \\
\hline Rx5day & $\begin{array}{l}\text { Max 5-day } \\
\text { precipitation amount }\end{array}$ & Monthly maximum consecutive 5-day precipitation & $\mathrm{Mm}$ \\
\hline SDII & $\begin{array}{l}\text { Simple daily intensity } \\
\text { index }\end{array}$ & $\begin{array}{l}\text { Annual total precipitation divided by the number of } \\
\text { wet days (defined as } \mathrm{PRCP}>=1.0 \mathrm{~mm} \text { ) in the year }\end{array}$ & $\begin{array}{l}\mathrm{Mm} / \\
\text { day }\end{array}$ \\
\hline
\end{tabular}




\begin{tabular}{|c|c|c|c|}
\hline ID* & Indicator name & Definitions & Units \\
\hline R10 & $\begin{array}{l}\text { Number of heavy } \\
\text { precipitation days }\end{array}$ & Annual count of days when $P R C P>=10 \mathrm{~mm}$ & Days \\
\hline R20 & $\begin{array}{l}\text { Number of very heavy } \\
\text { precipitation days }\end{array}$ & Annual count of days when $P R C P>=20 \mathrm{~mm}$ & Days \\
\hline Rnn & $\begin{array}{l}\text { Number of days above } \\
\mathrm{nn} \mathrm{mm}\end{array}$ & $\begin{array}{l}\text { Annual count of days when } \mathrm{PRCP}>=\mathrm{nn} \mathrm{mm}, \mathrm{nn} \text { is } \\
\text { user defined threshold }\end{array}$ & Days \\
\hline CDD & Consecutive dry days & $\begin{array}{l}\text { Maximum number of consecutive days with } \\
\mathrm{RR}<1 \mathrm{~mm}\end{array}$ & Days \\
\hline CWD & Consecutive wet days & $\begin{array}{l}\text { Maximum number of consecutive days with } \\
\mathrm{RR}>=1 \mathrm{~mm}\end{array}$ & Days \\
\hline R95p & Very wet days & Annual total $\mathrm{PRCP}$ when $\mathrm{RR}>95^{\text {th }}$ percentile & $\mathrm{Mm}$ \\
\hline R99p & Extremely wet days & Annual total PRCP when $\mathrm{RR}>99^{\text {th }}$ percentile & $\mathrm{Mm}$ \\
\hline $\begin{array}{l}\text { PRCP- } \\
\text { TOT }\end{array}$ & $\begin{array}{l}\text { Annual total wet-day } \\
\text { precipitation }\end{array}$ & Annual total PRCP in wet days $(\mathrm{RR}>=1 \mathrm{~mm})$ & $\mathrm{Mm}$ \\
\hline
\end{tabular}

* All indices and definitions from Zhang and Yang, 2004. 